LAWRENCE LIVERMORE NATIONAL LABORATORY

Asian Summer Monsoon Intraseasonal Variability in General Circulation Models

K. R. Sperber and H. Annamalai

March 1, 2004 


\section{Disclaimer}

This document was prepared as an account of work sponsored by an agency of the United States Government. Neither the United States Government nor the University of California nor any of their employees, makes any warranty, express or implied, or assumes any legal liability or responsibility for the accuracy, completeness, or usefulness of any information, apparatus, product, or process disclosed, or represents that its use would not infringe privately owned rights. Reference herein to any specific commercial product, process, or service by trade name, trademark, manufacturer, or otherwise, does not necessarily constitute or imply its endorsement, recommendation, or favoring by the United States Government or the University of California. The views and opinions of authors expressed herein do not necessarily state or reflect those of the United States Government or the University of California, and shall not be used for advertising or product endorsement purposes.

\section{Auspices Statement}

This work was performed under the auspices of the U.S. Department of Energy by University of California, Lawrence Livermore National Laboratory under Contract W-7405-Eng-48. 


\title{
Asian Summer Monsoon Intraseasonal Variability in General Circulation Models
}

\author{
K. R. Sperber ${ }^{1}$ and H. Annamalai ${ }^{2}$ \\ ${ }^{1}$ Program for Climate Model Diagnosis and Intercomparison \\ Lawrence Livermore National Laboratory \\ P.O. Box 808, L-103 \\ Livermore, CA 94550 USA \\ (sperber1@llnl.gov) \\ ${ }^{2}$ International Pacific Research Center/SOEST \\ University of Hawaii \\ 1680 East West Road \\ Honolulu, HI 96822 USA
}




\section{Goals}

1) Analyze boreal summer Asian monsoon intraseasonal variability general circulation models

-How well do the models represent the eastward and northward propagating components of the convection? -How well do the models represent the interactive control that the western tropical Pacific rainfall exerts on the rainfall over India and vice-versa?

2) Role of air-sea interactions

-prescribed vs. interactive ocean

3) Mean monsoon vs. variability 


\section{Data}

1) Observations (JJAS: 1979-95)

-NCEP/NCAR Reanalysis

-AVHRR OLR

-CMAP Rainfall

2) ECHO-G (ECHAM4.6/HOPE) (JJAS: 19 years; CMIP2+) -flux corrected -has an excellent boreal winter MJO

All data are filtered with a 20-100 day Lanczos filter 


\section{JJAS Climatology}

a) CMAP rainfall and NCEP/NCAR 850hPa wind

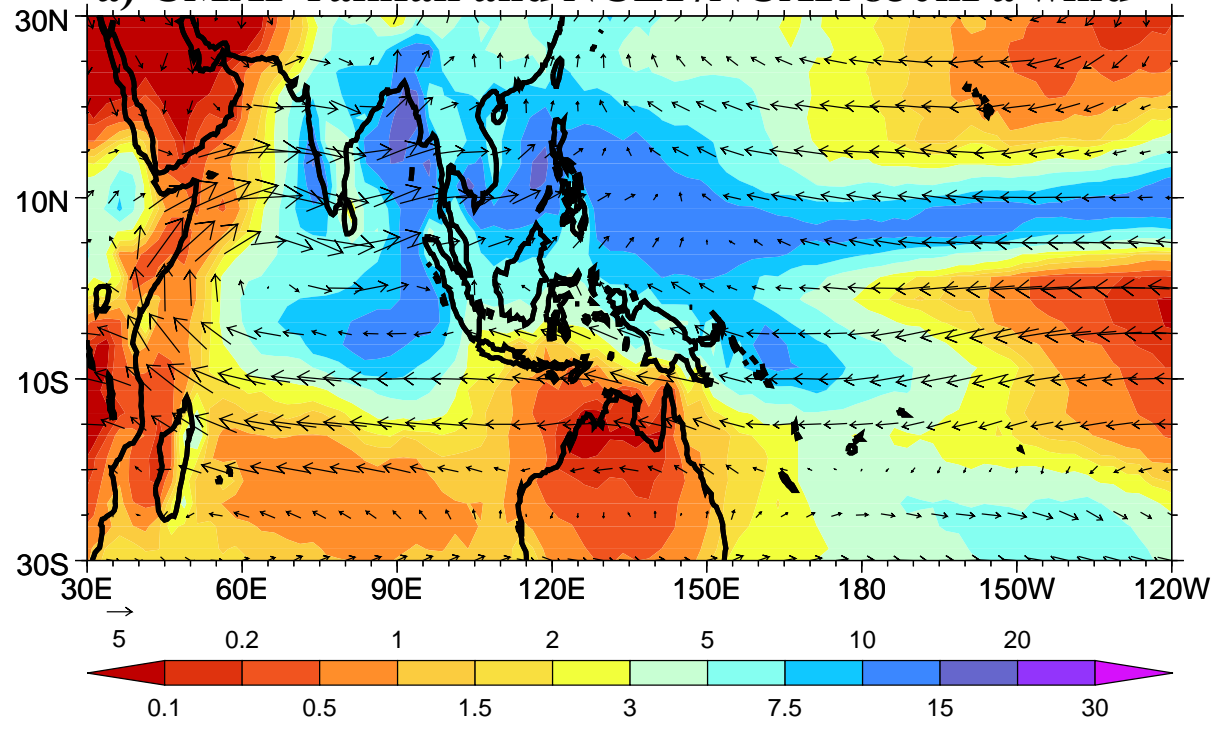

b) ECHO-G rainfall and $850 \mathrm{hPa}$ wind

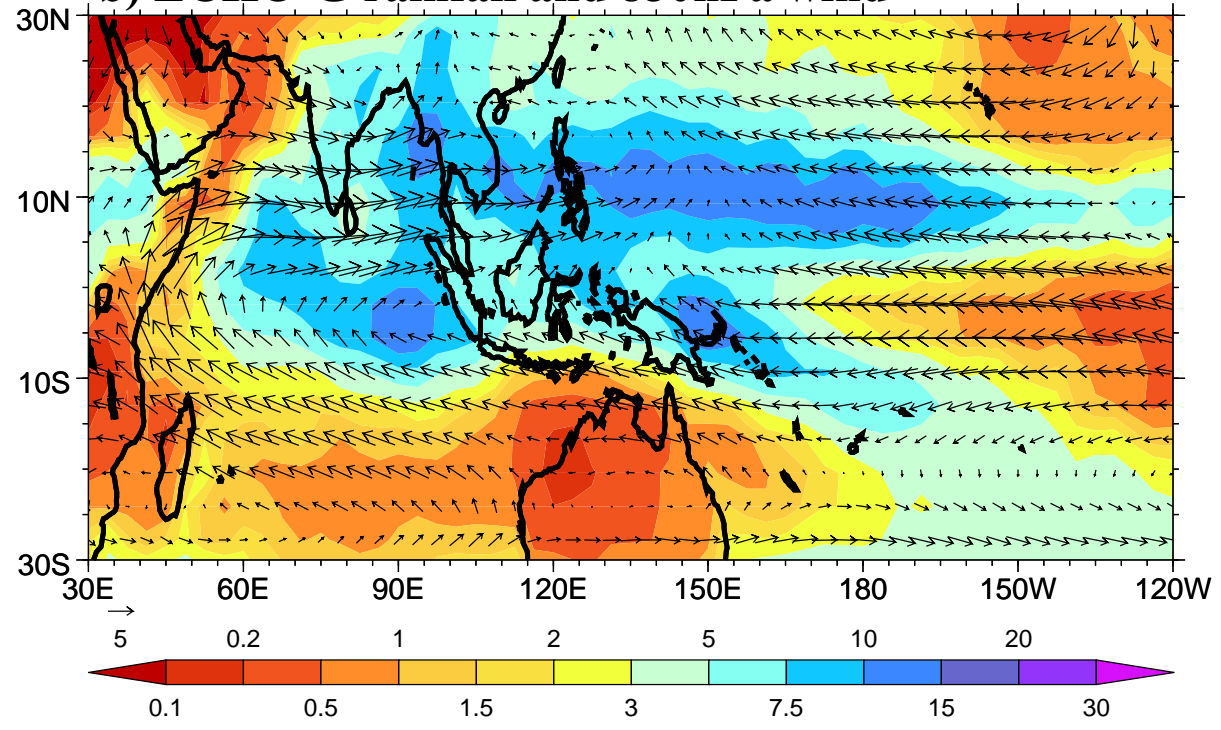

c) Rainfall (ECHO-G - CMAP)

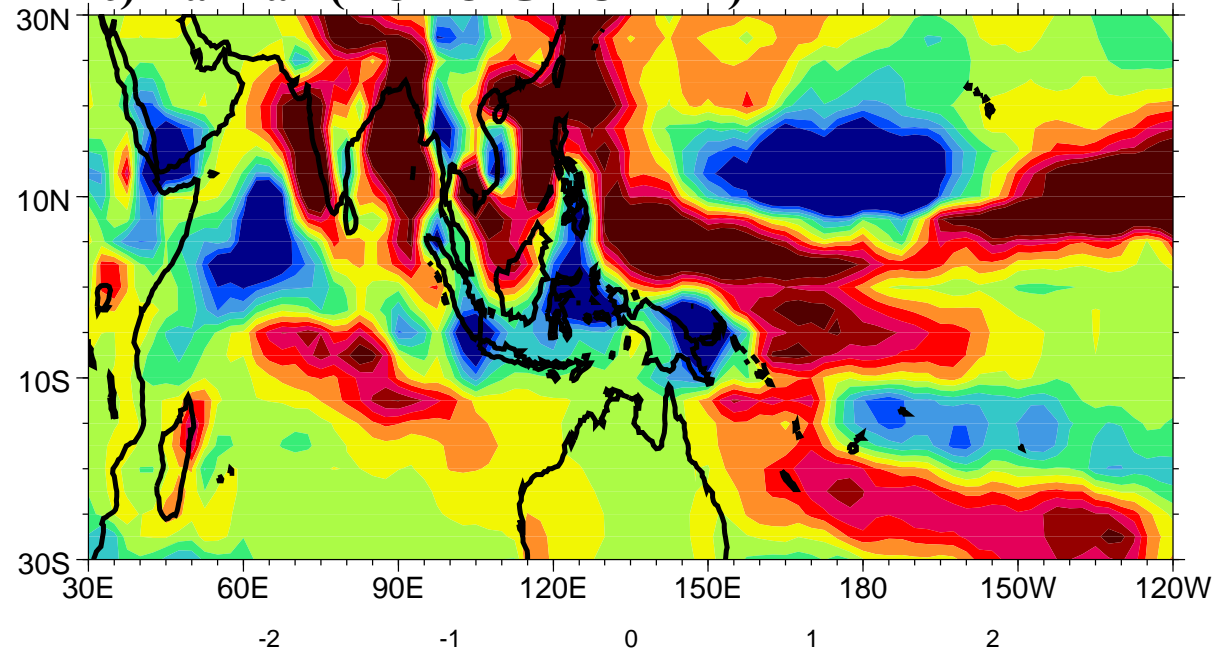




\section{JJAS Climatology}

a) NCEP/NCAR SST and ground temperature

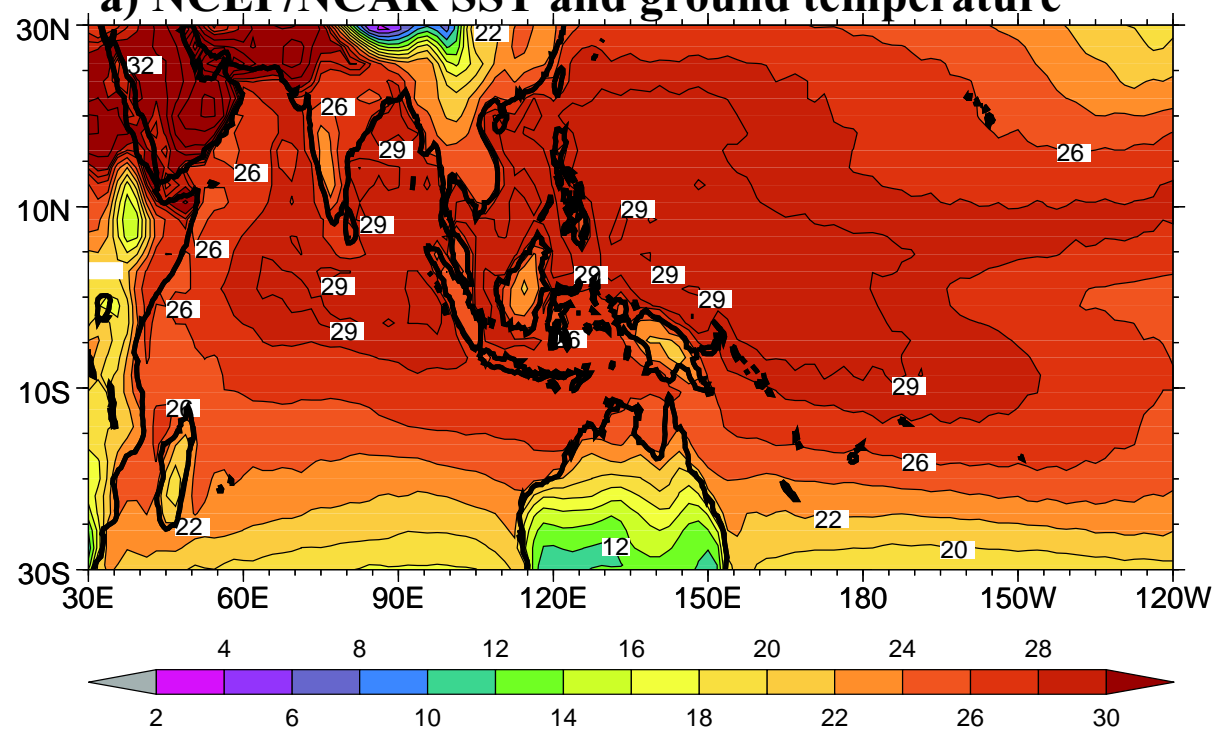

b) ECHO-G SST and ground temperature
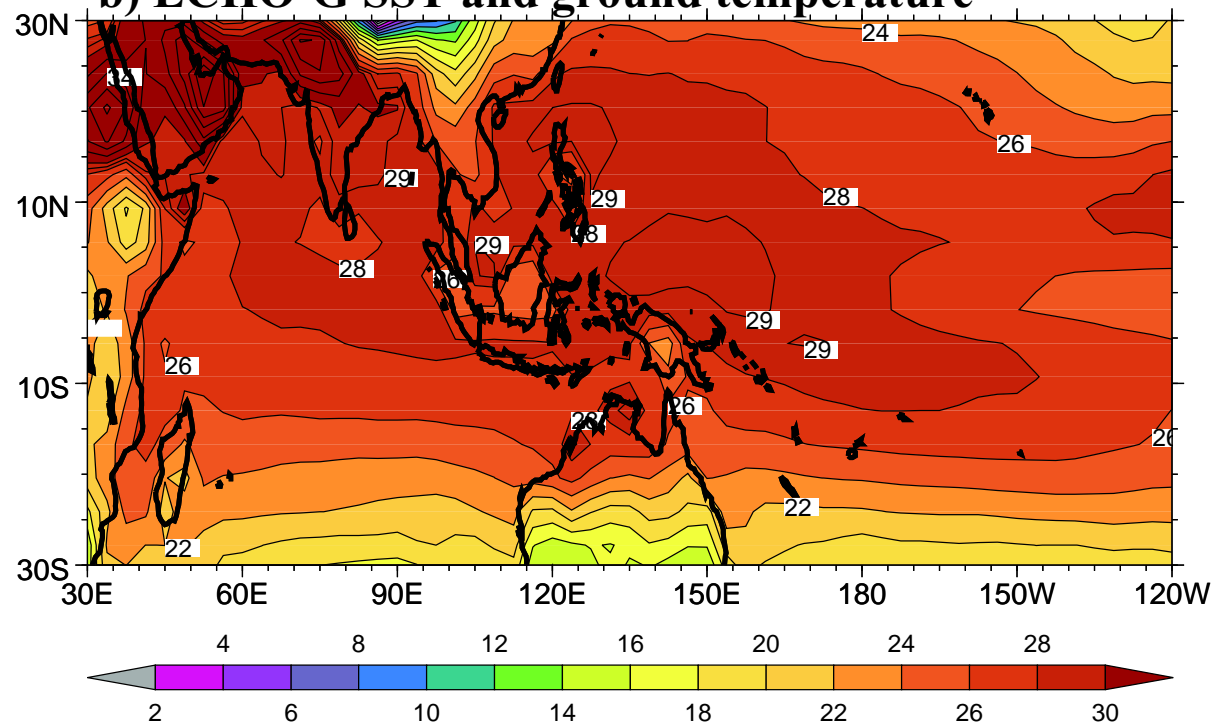

c) SST and ground temperature (ECHO-G - NCEP/NCAR)

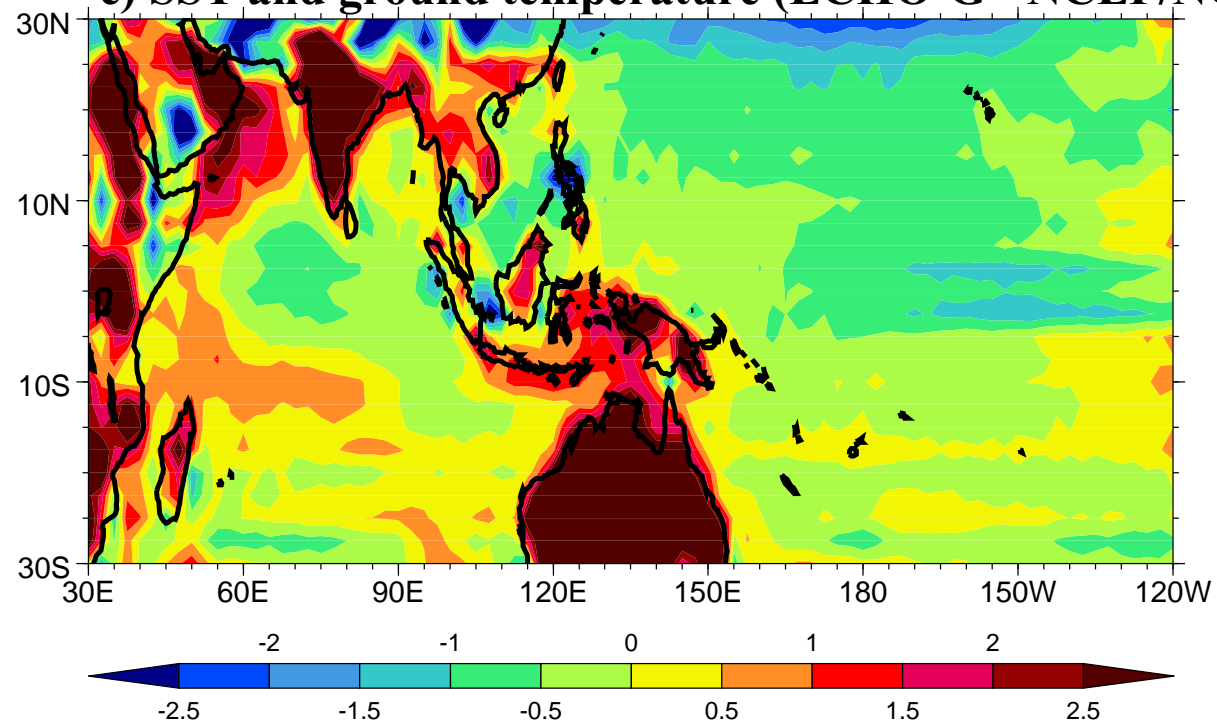




\section{JJAS Climatology}

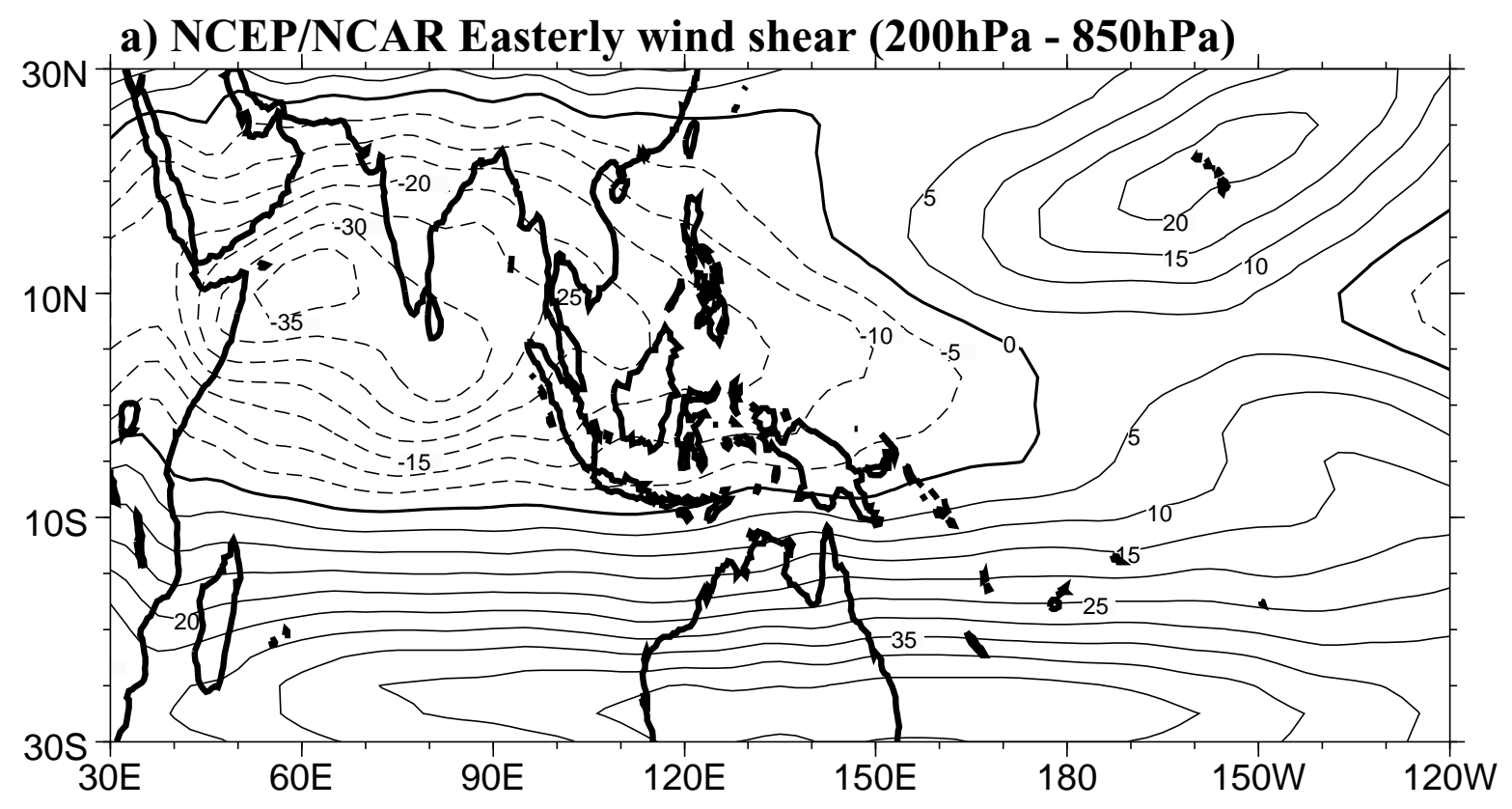

b) ECHO-G Easterly wind shear $(200 \mathrm{hPa}-850 \mathrm{hPa})$

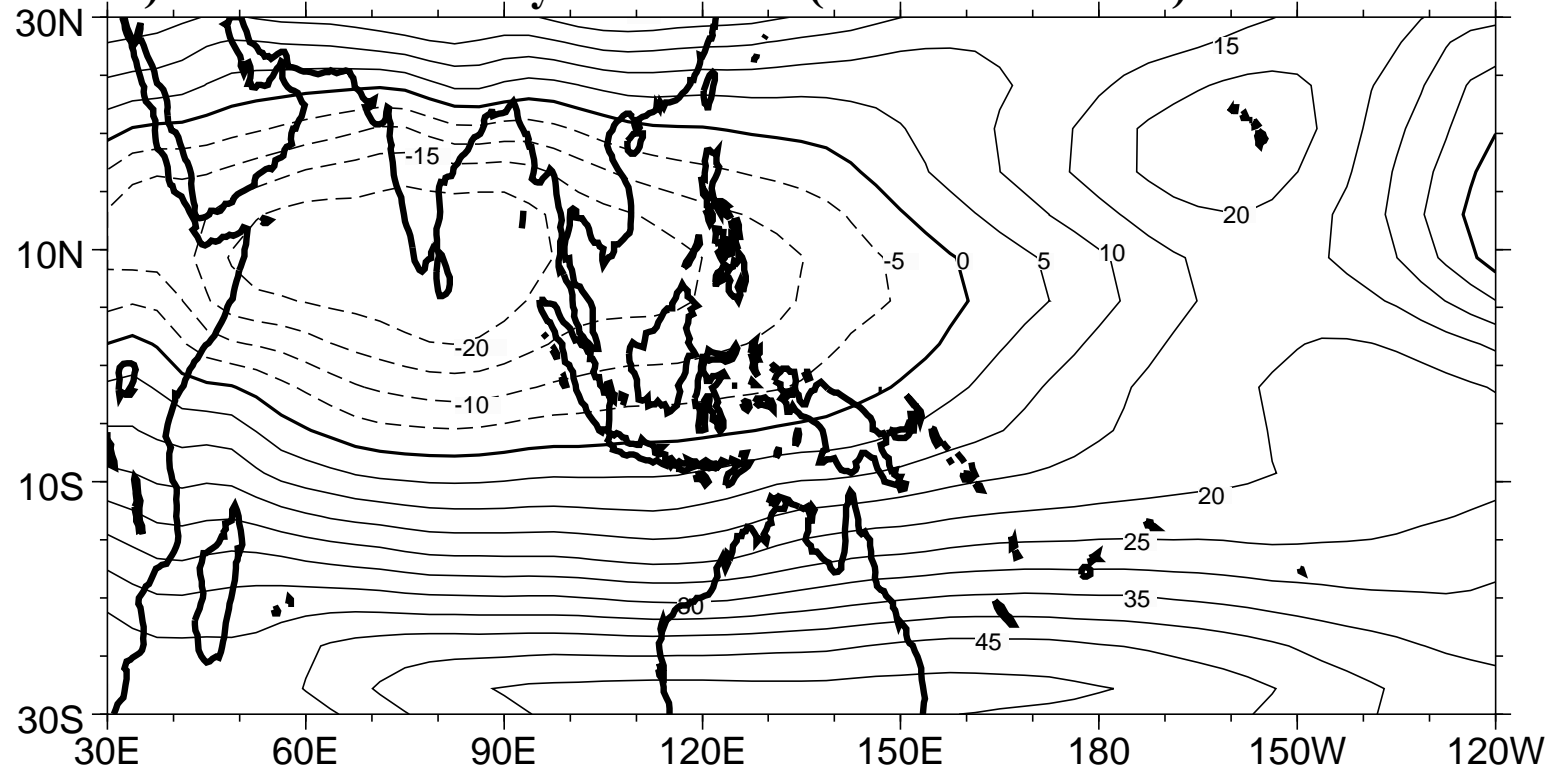




\section{AVHRR OLR (1979-95: JJAS) ECHO-G OLR (19 years: JJAS)}

a) Mean

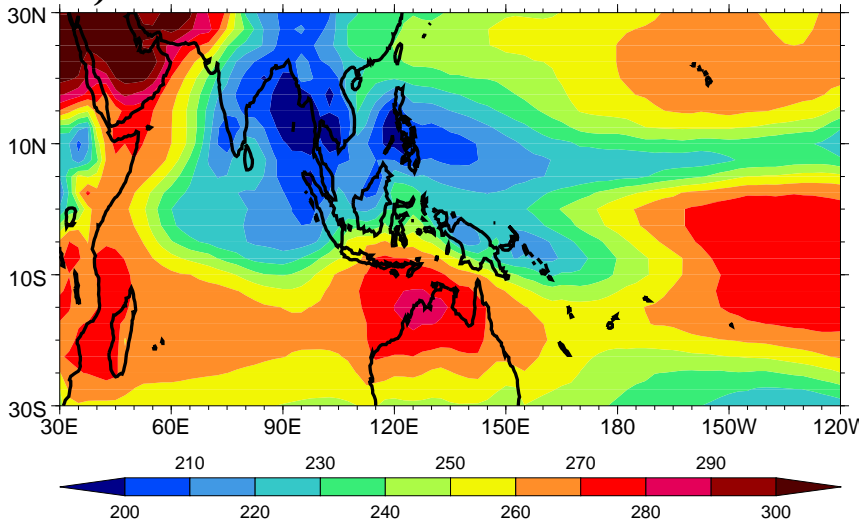

b) Variance

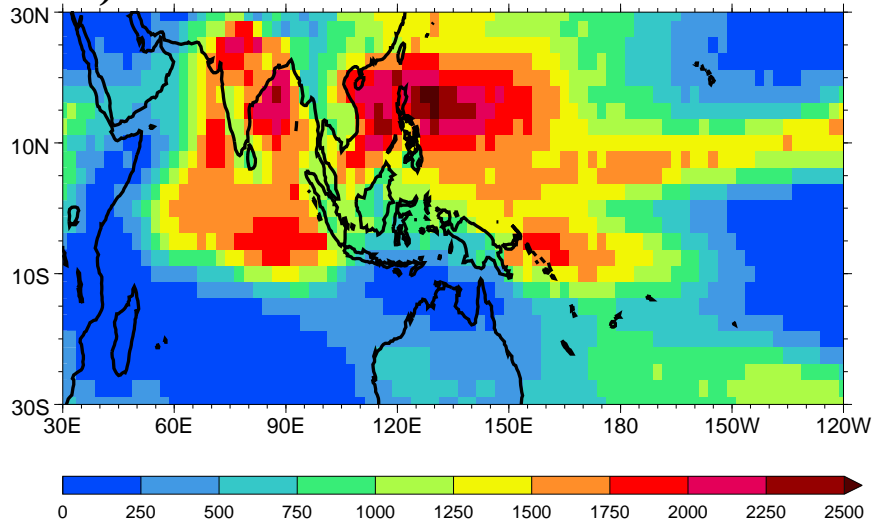

c) 20-100 day filtered variance

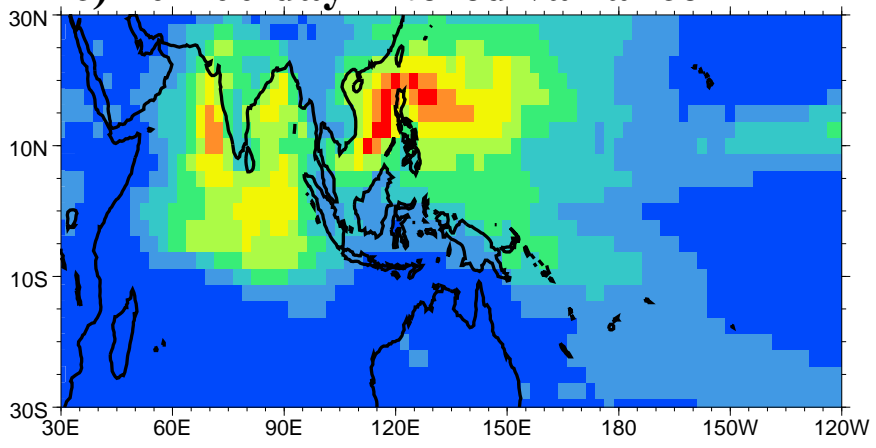

d)\% variance explained by filtered data

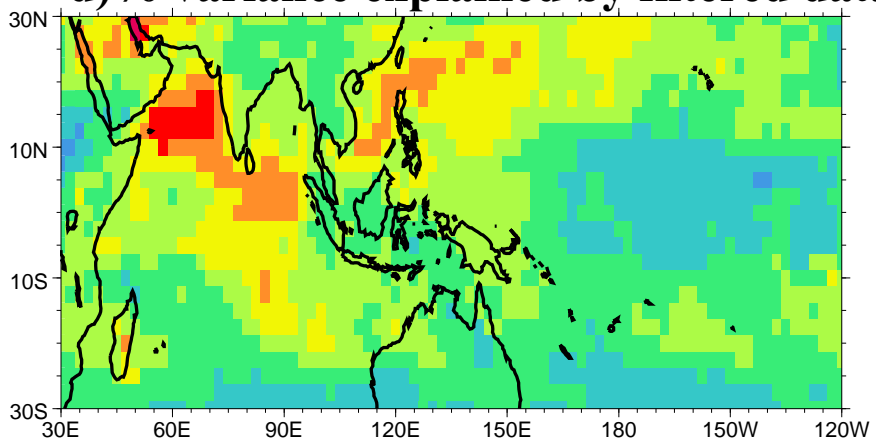

e) Mean

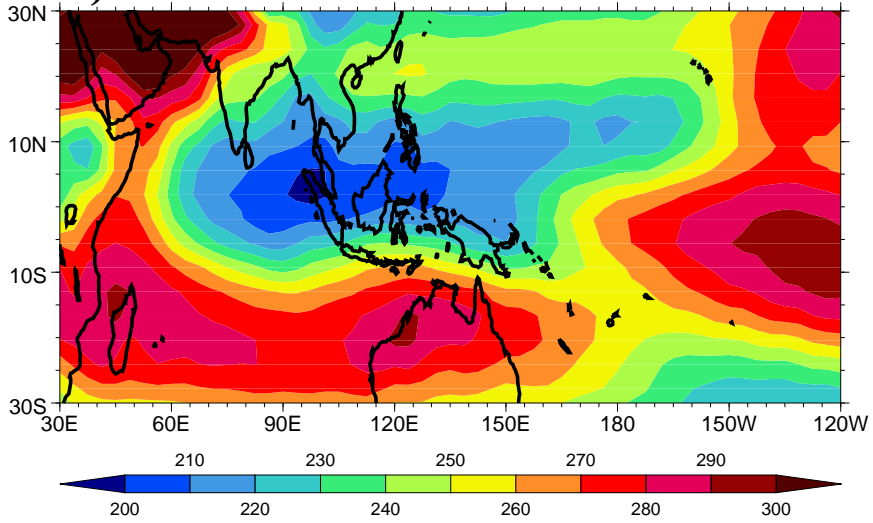

f) Variance

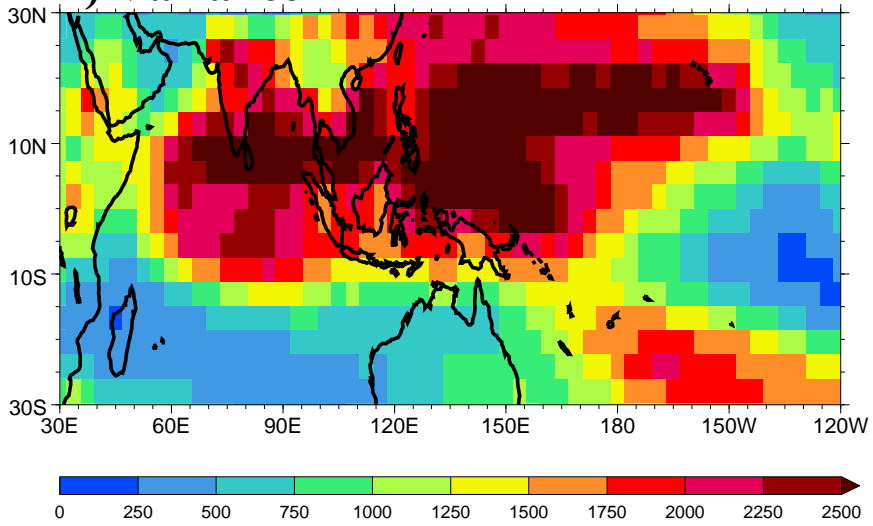

g) 20-100 day filtered variance

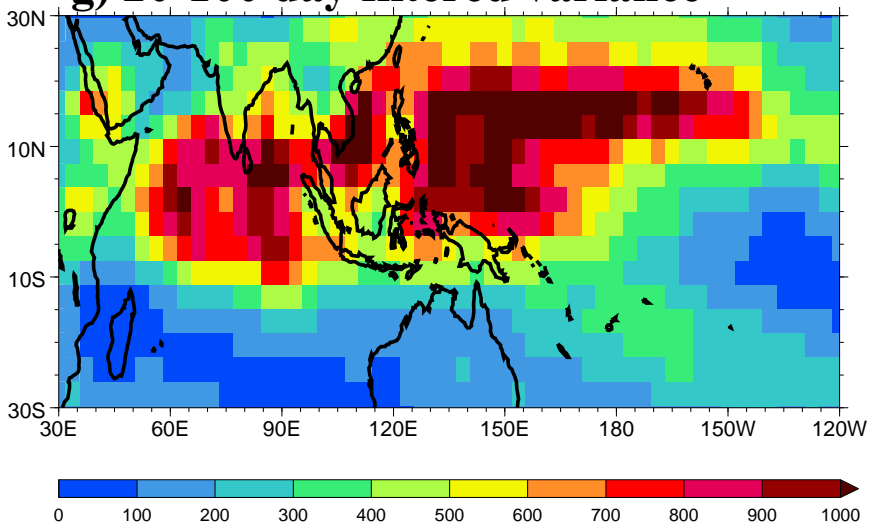

h)\% variance explained by filtered data

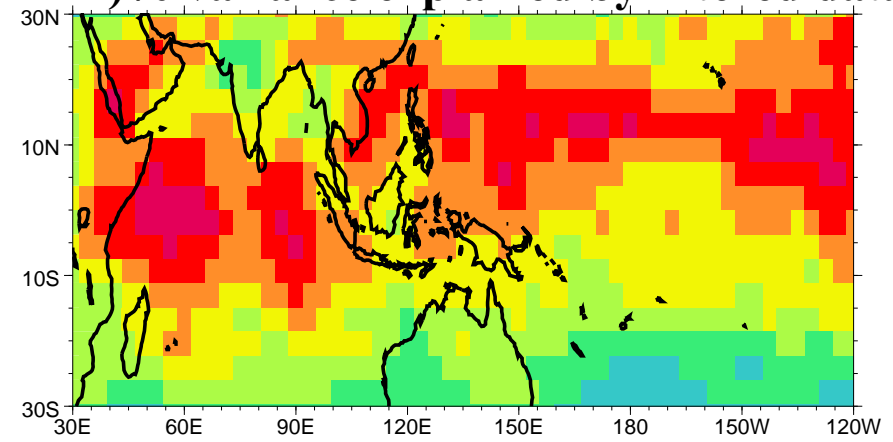




\section{AVHRR OLR (1979-95: JJAS) \\ Cyclostationary EOF's (40-day nested period)}

a) Day -15

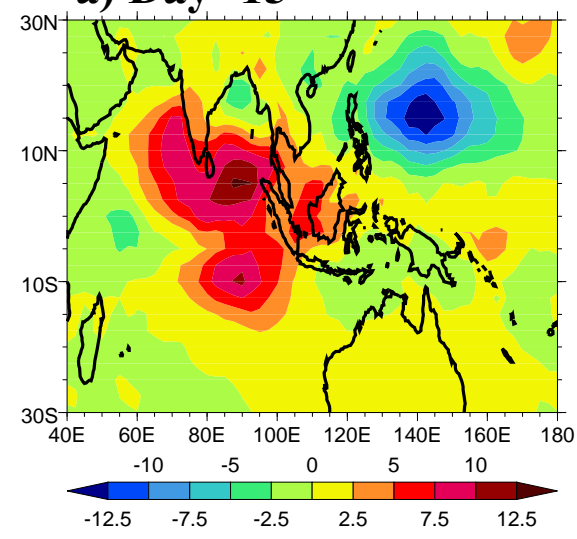

b) Day -10

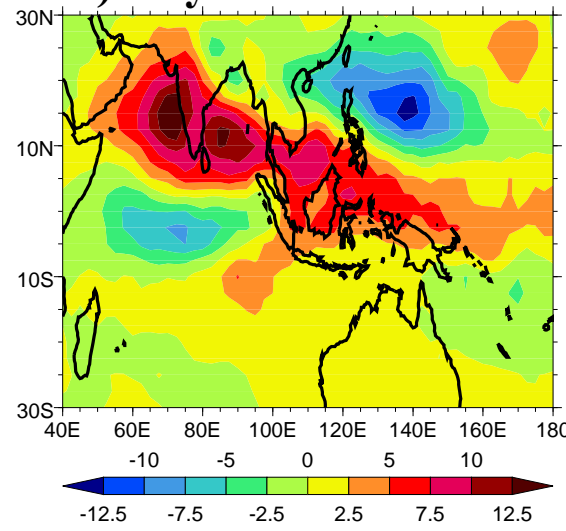

c) Day -5

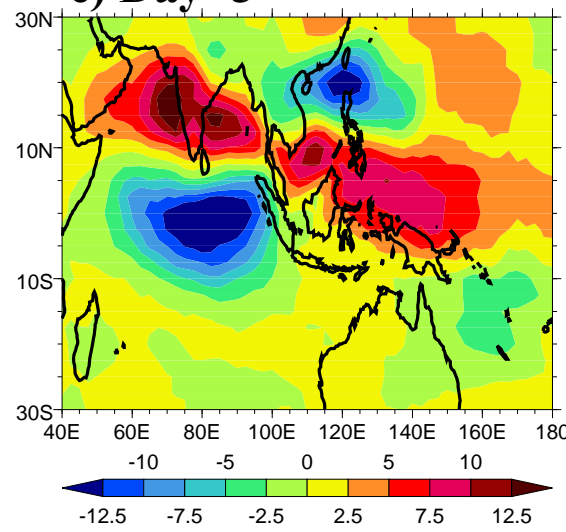

d) Day 0

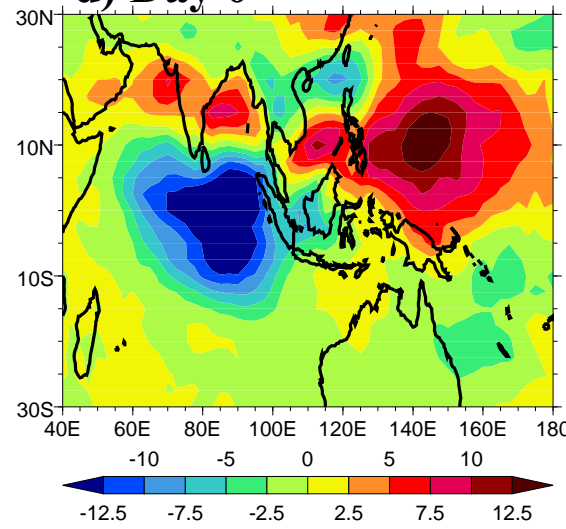

e) Day 5

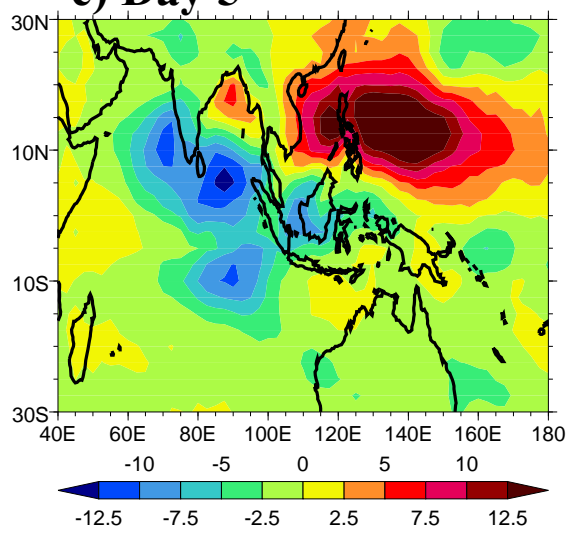

f) Day 10

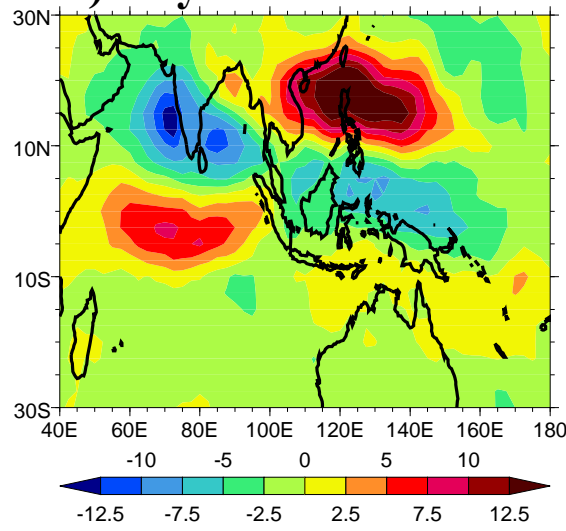

g) Day 15

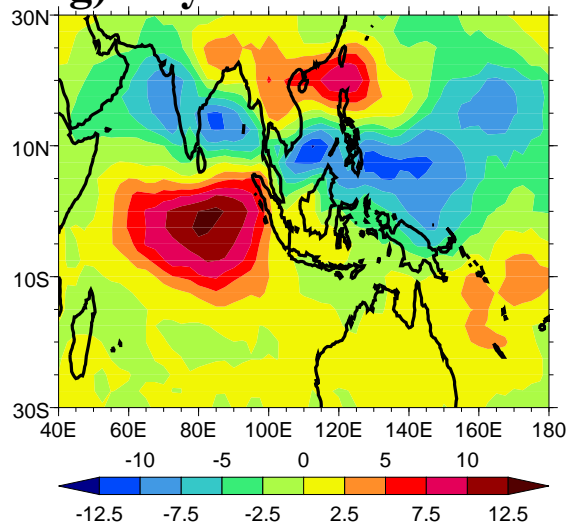

h) Day 20

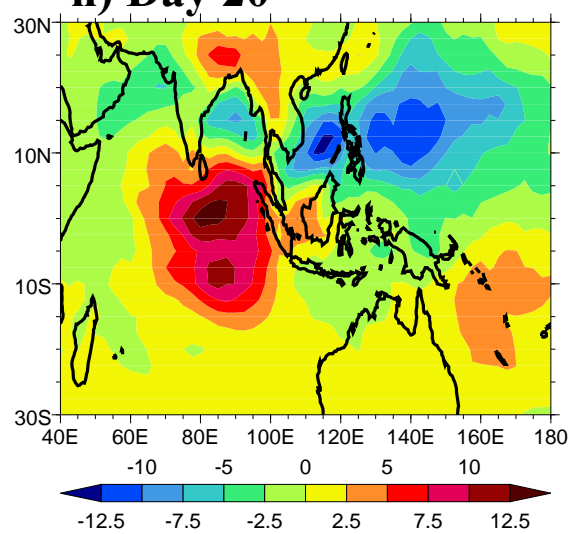




\section{ECHO-G OLR (19 years: JJAS) PC-4 Linear Regression with OLR}

a) Day -15

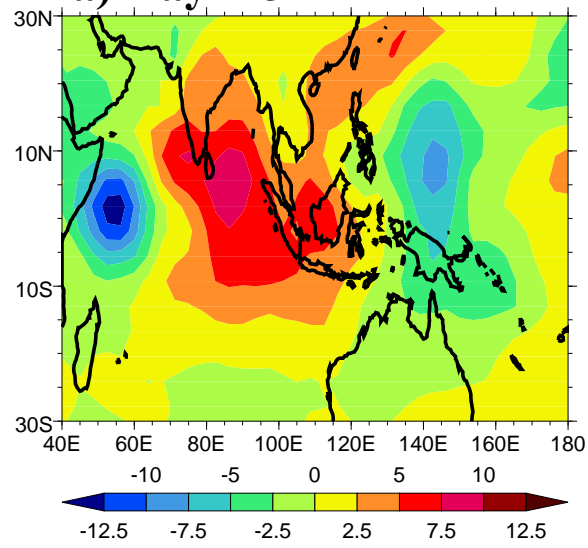

b) Day -10

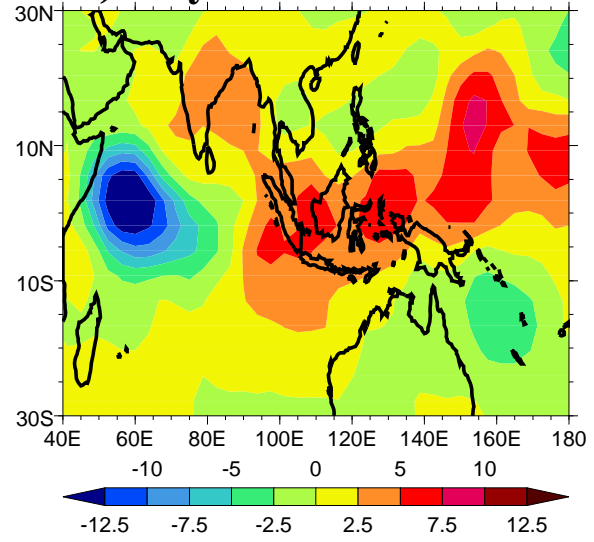

c) Day $-\mathbf{5}$

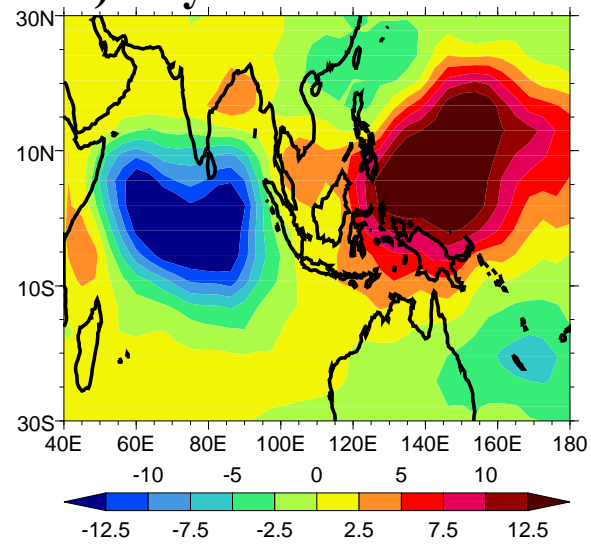

d) Day 0

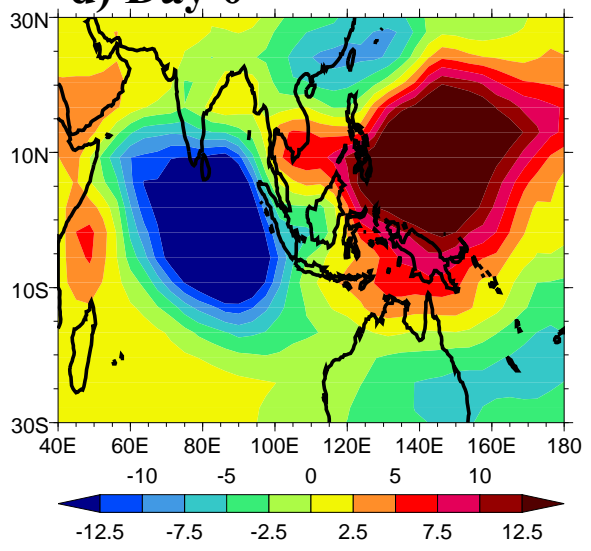

e) Day 5

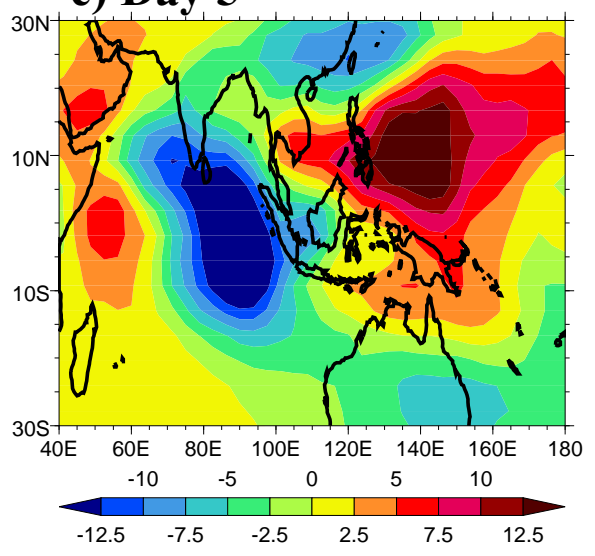

f) Day 10

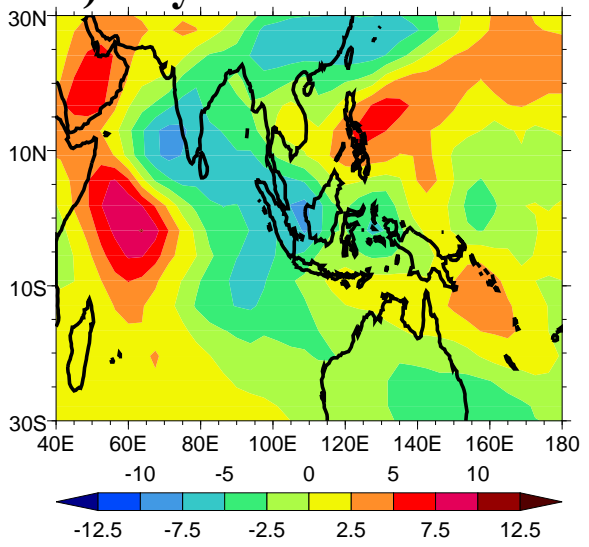

g) Day 15

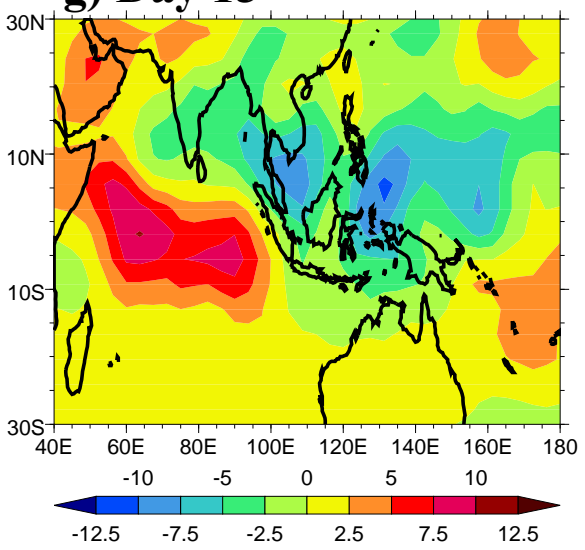

h) Day 20

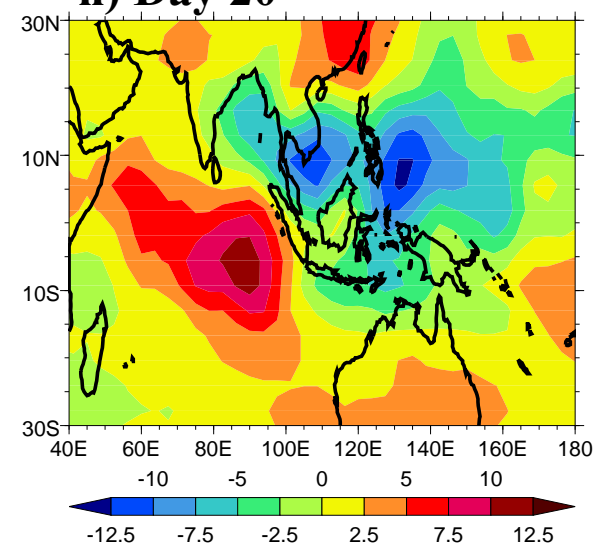




\section{Onset in the Western Indian Ocean (Day -15) \\ Observations \\ ECHO-G}

a) CMAP Rainfall and $850 \mathrm{hPa}$ wind

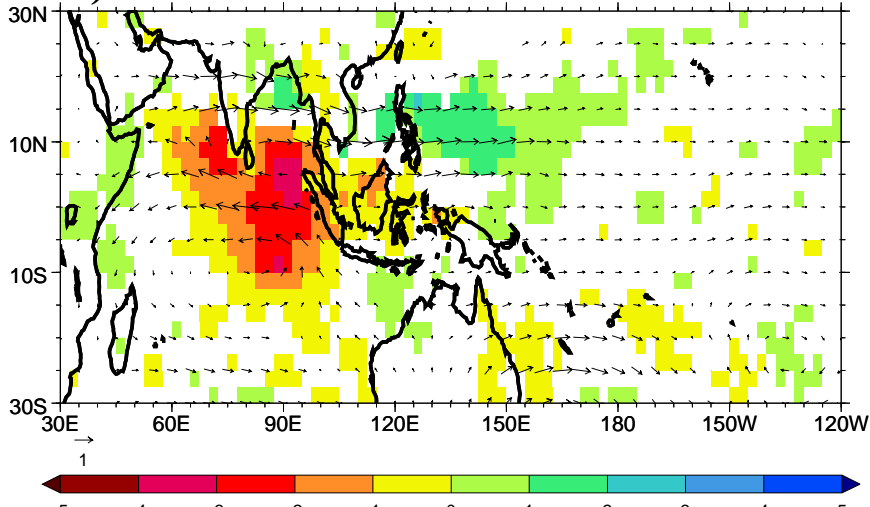

b) Surface Temperature and wind

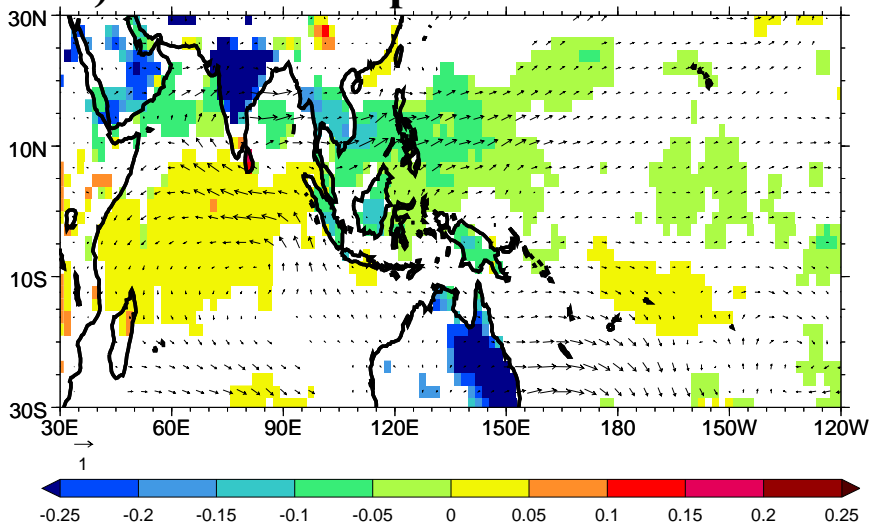

c) $1000 \mathrm{hPa}$ Divergence
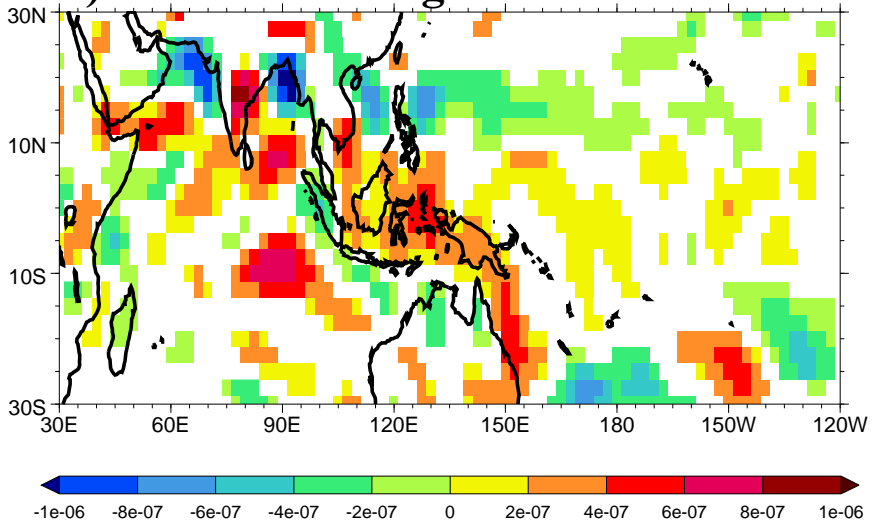

d) 850hPa Specific Humidity

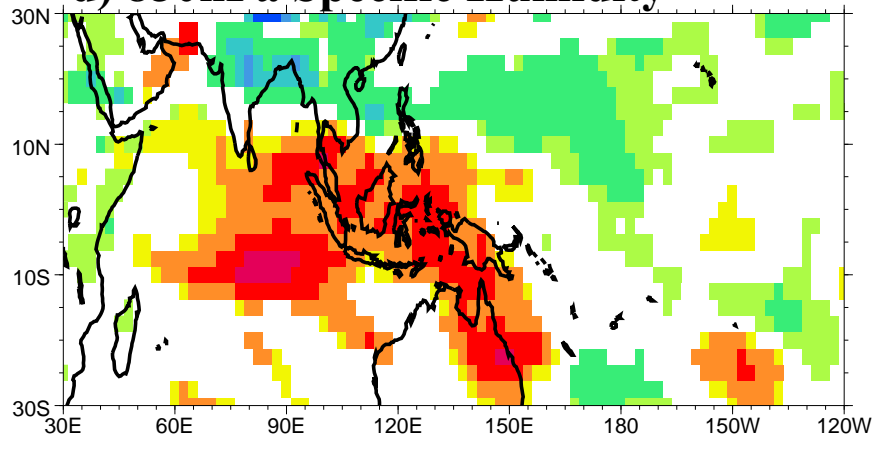

\begin{tabular}{|cccc|c|c|c|ccc|c|}
\hline-0.0005 & -0.0004 & -0.0003 & -0.0002 & -0.0001 & 0 & 0.0001 & 0.0002 & 0.0003 & 0.0004 & 0.0005
\end{tabular} e) Rainfall and $850 \mathrm{hPa}$ wind

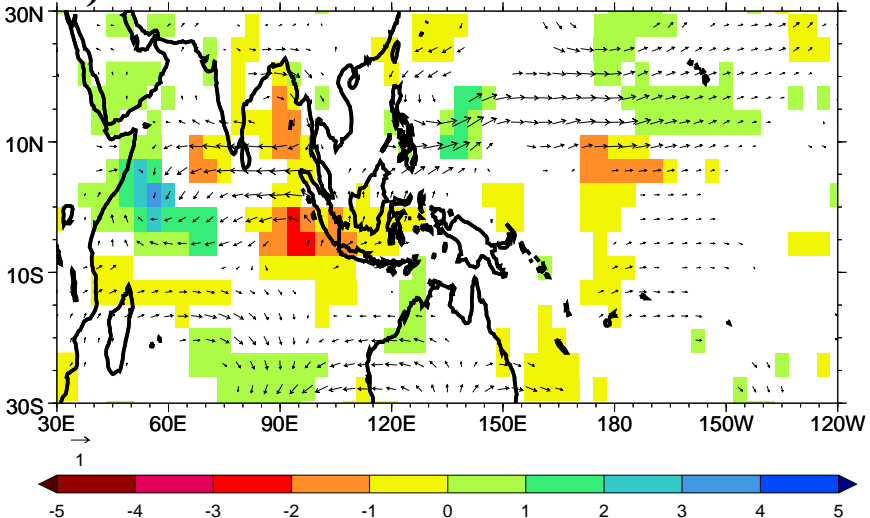

f) Surface Temperature and wind

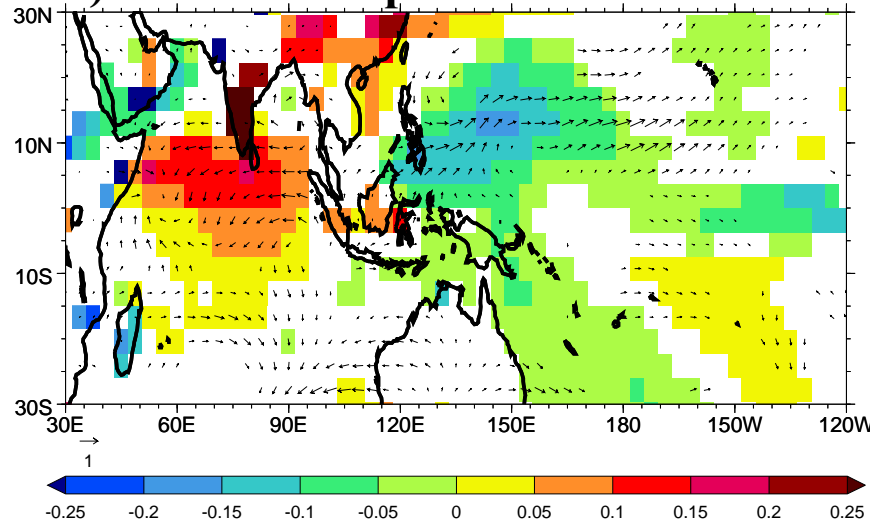

g) $1000 \mathrm{hPa}$ Divergence

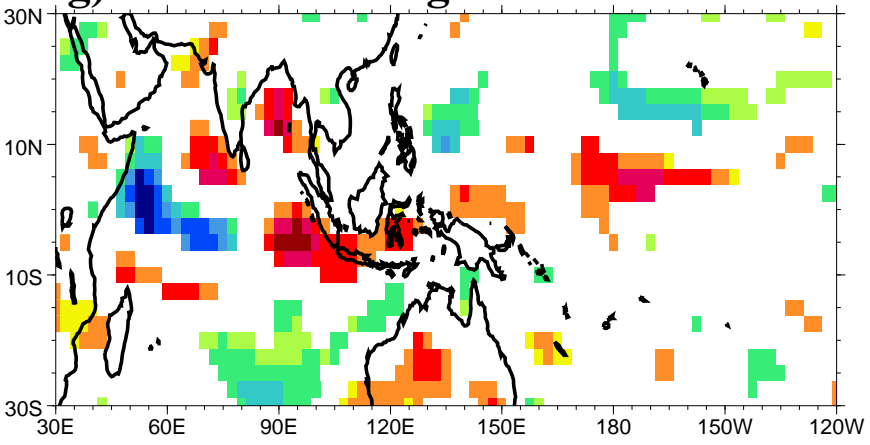

h) 850hPa Specific Humidity

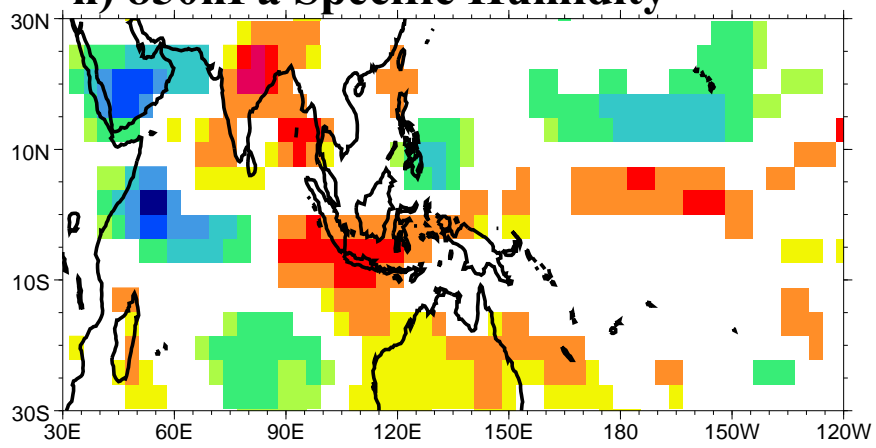


Northward Propagation of Convection Begins (Day 0)

Observations

a) CMAP Rainfall and $850 \mathrm{hPa}$ wind

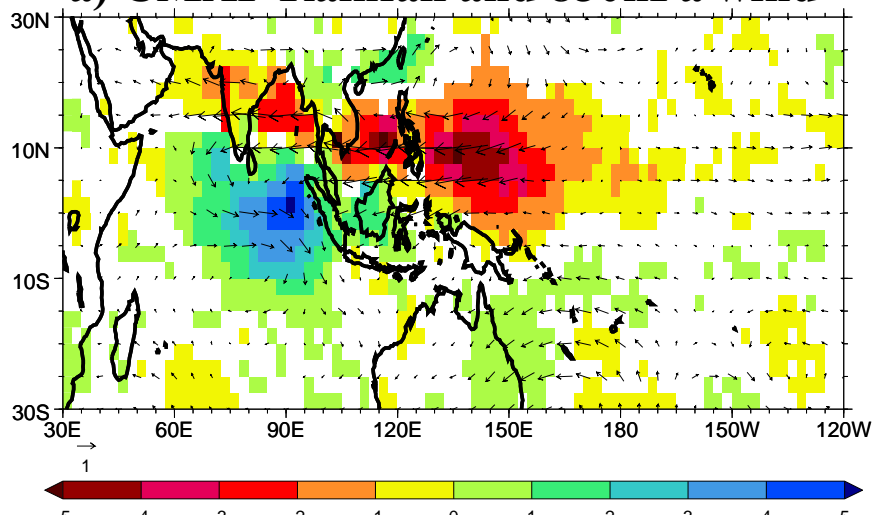

b) Surface Temperature and wind

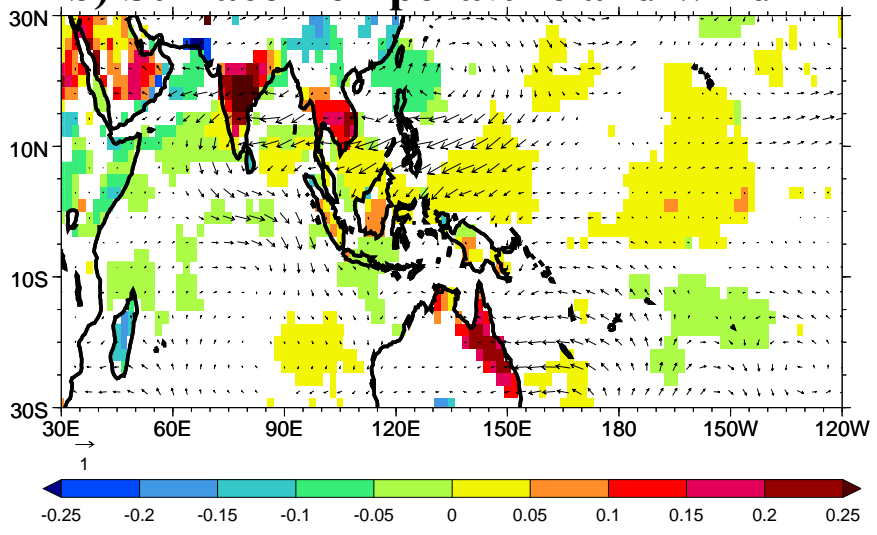

c) $1000 \mathrm{hPa}$ Divergence
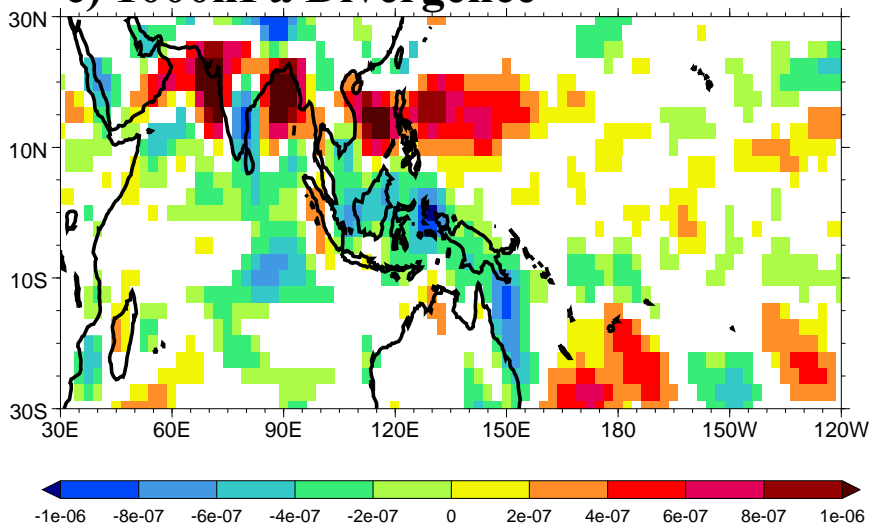

d) 850hPa Specific Humidity

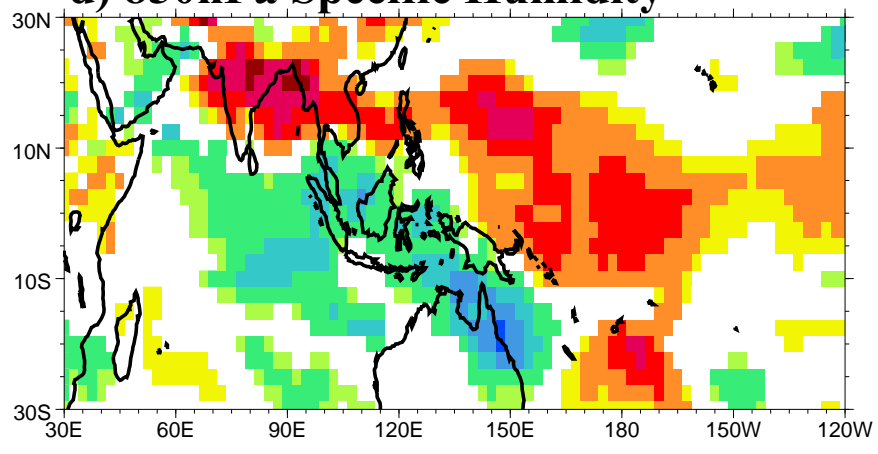

\begin{tabular}{lllll|l|lll|ll|l}
\hline-0.0005 & -0.0004 & -0.0003 & -0.0002 & -0.0001 & 0 & 0.0001 & 0.0002 & 0.0003 & 0.0004 & 0.0005
\end{tabular}
ECHO-G

e) Rainfall and $850 \mathrm{hPa}$ wind

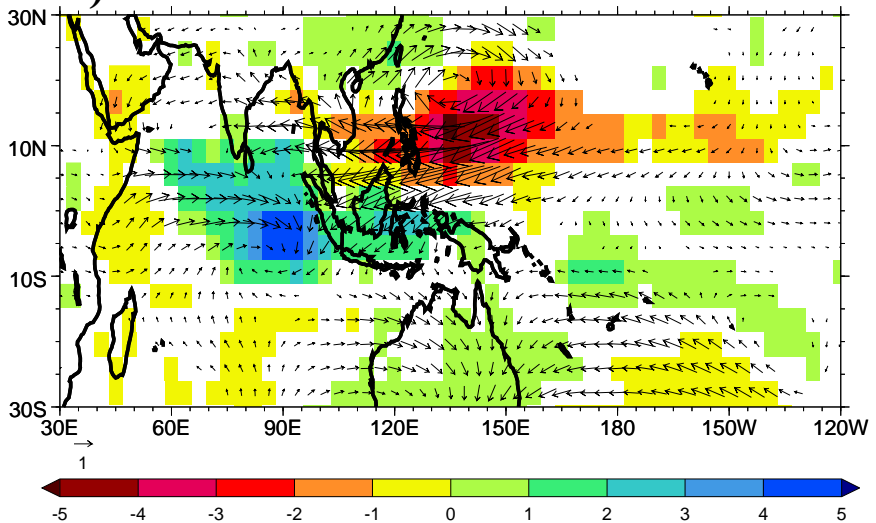

f) Surface Temperature and wind

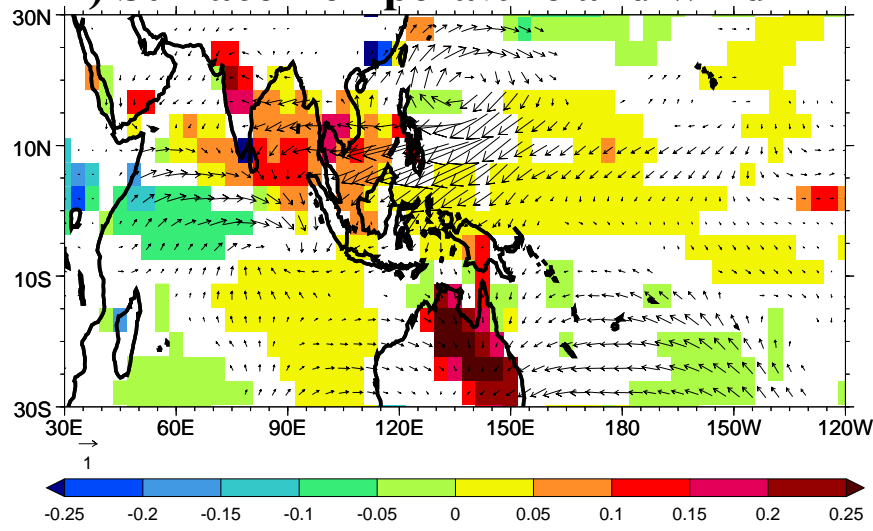

g) $1000 \mathrm{hPa}$ Divergence

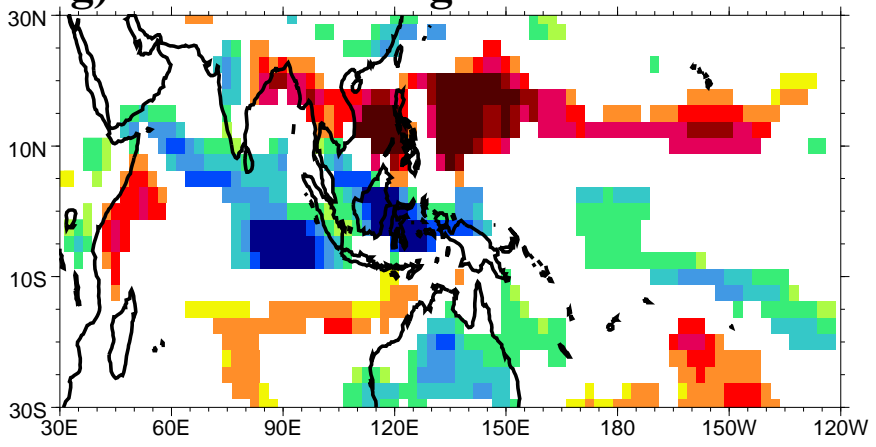

h) 850hPa Specific Humidity

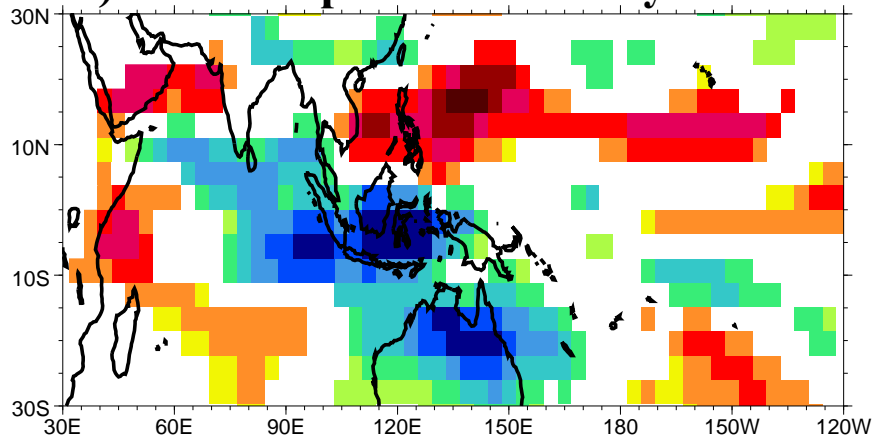

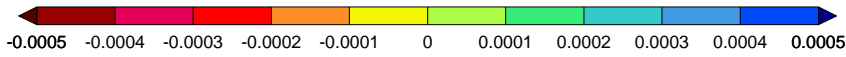




\section{$71.25^{\circ} \mathrm{E}-83.75^{\circ} \mathrm{E}$ Lag-Latitude Regressions \\ Observations \\ ECHO-G}

a) CMAP Rainfall and AVHRR OLR

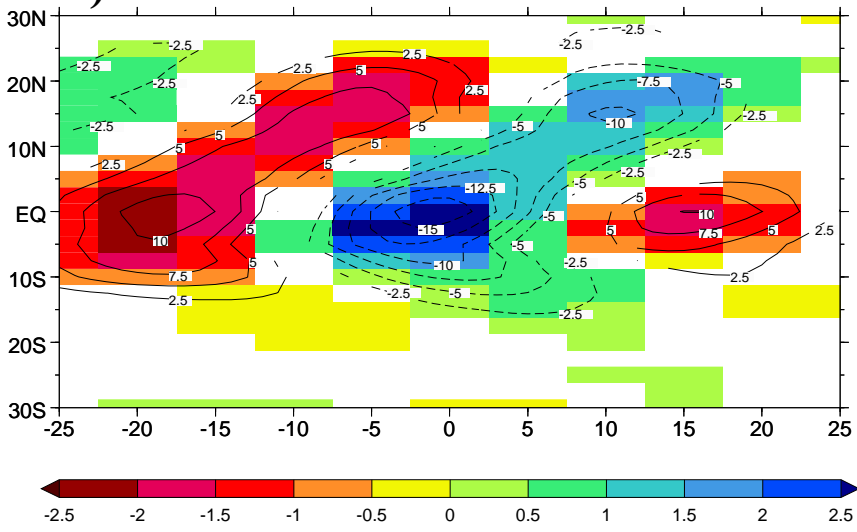

b) SST and Ground Temperature

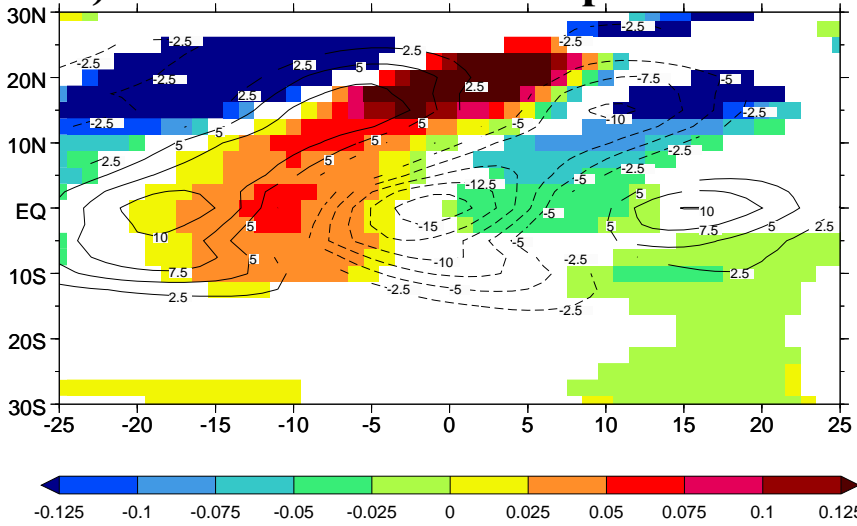

c) $1000 \mathrm{hPa}$ Divergence

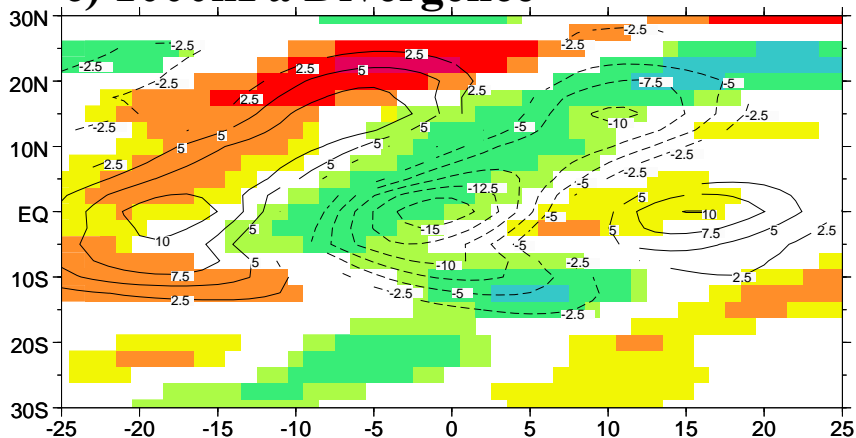

d) 1000hPa Specific Humidity

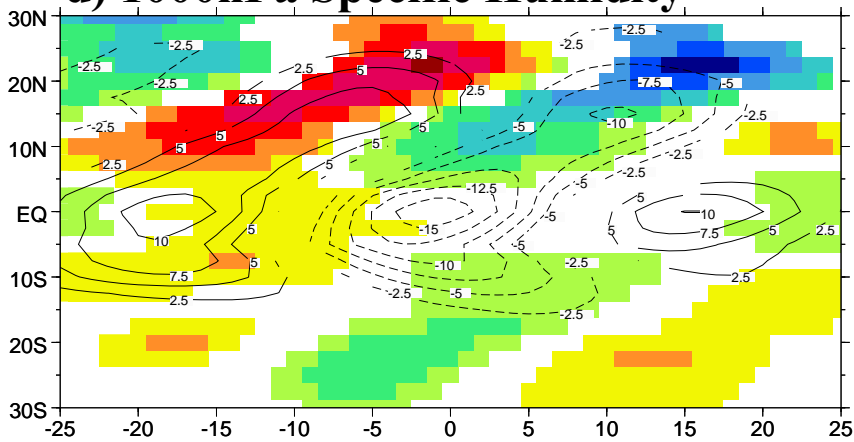

\begin{tabular}{cccc|c|ccccc|c|}
\hline-0.0005 & -0.0004 & -0.0003 & -0.0002 & -0.0001 & 0 & 0.0001 & 0.0002 & 0.0003 & 0.0004 & 0.0005
\end{tabular} e) OLR and Rainfall

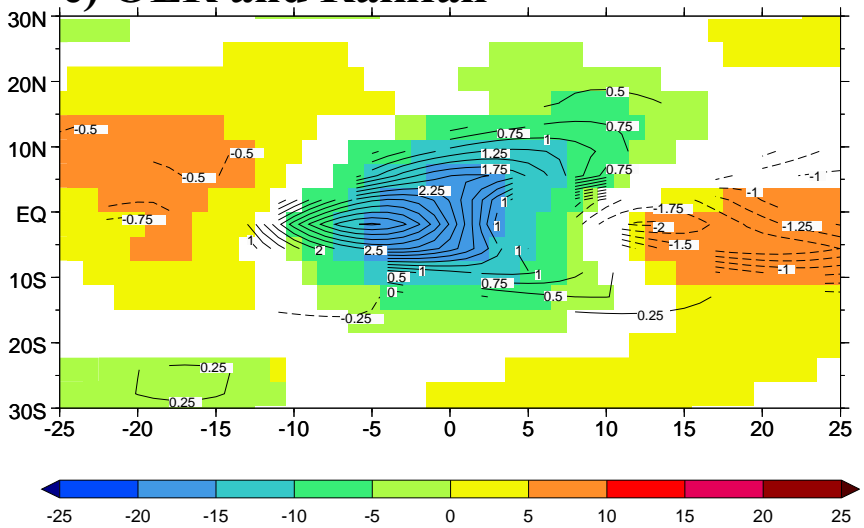

f) SST and Ground Temperature

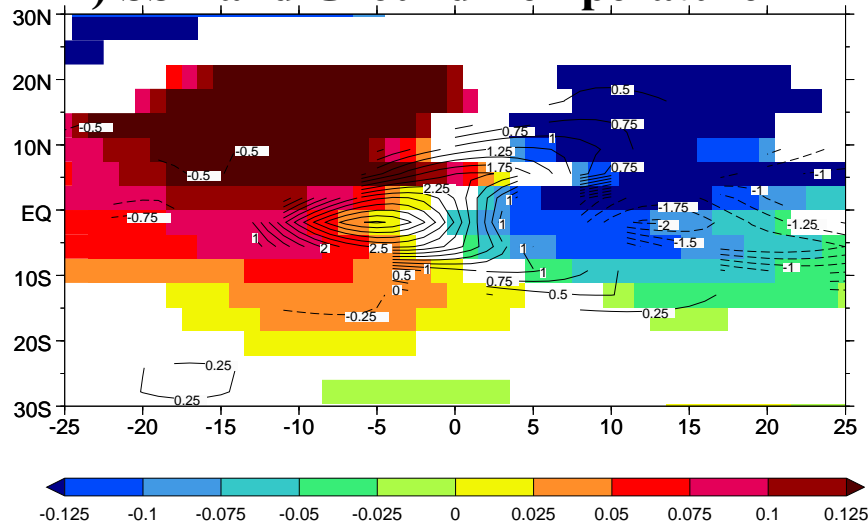

g) $1000 \mathrm{hPa}$ Divergence

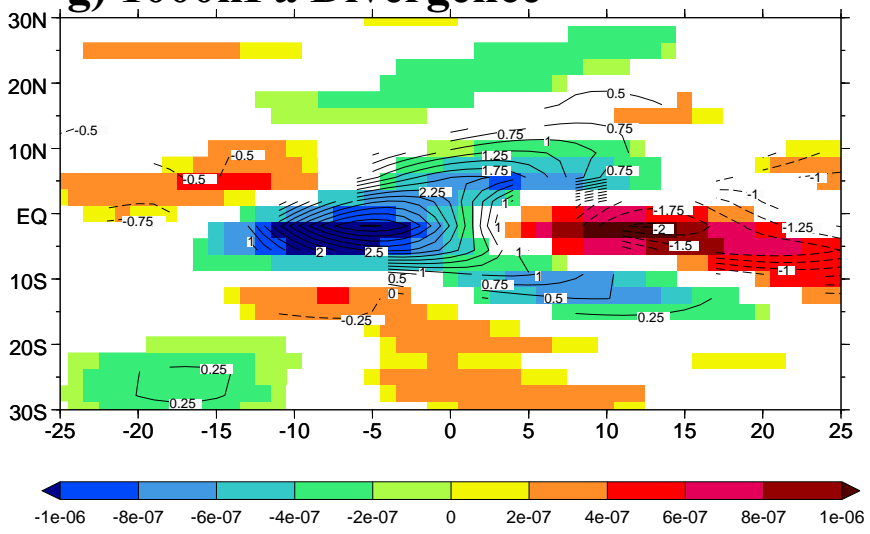

h) 1000hPa Specific Humidity

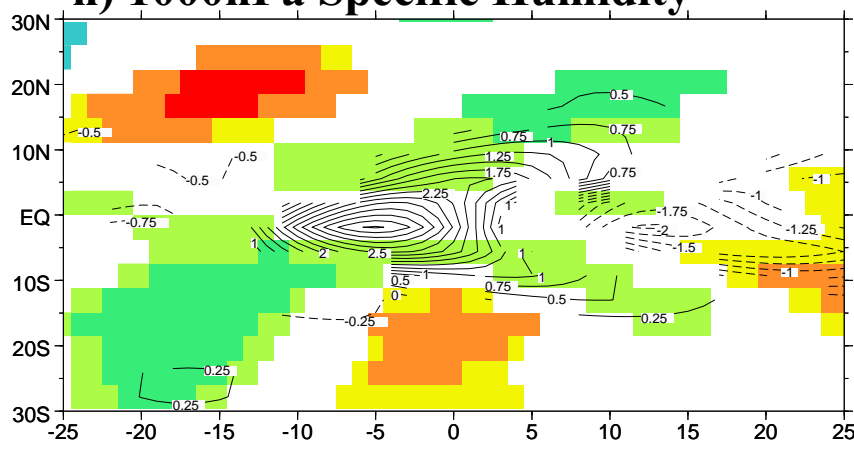




\section{$5^{\circ} \mathrm{N}-5^{\circ} \mathrm{S}$ Longitude-Pressure Level Regressions (Day 0) \\ Observations \\ ECHO-G}

a) Divergence
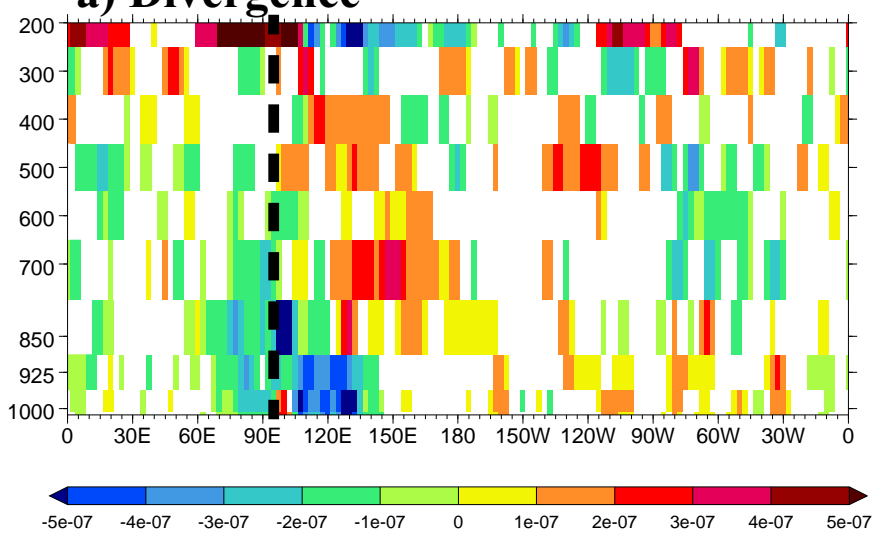

b) Specific humidity
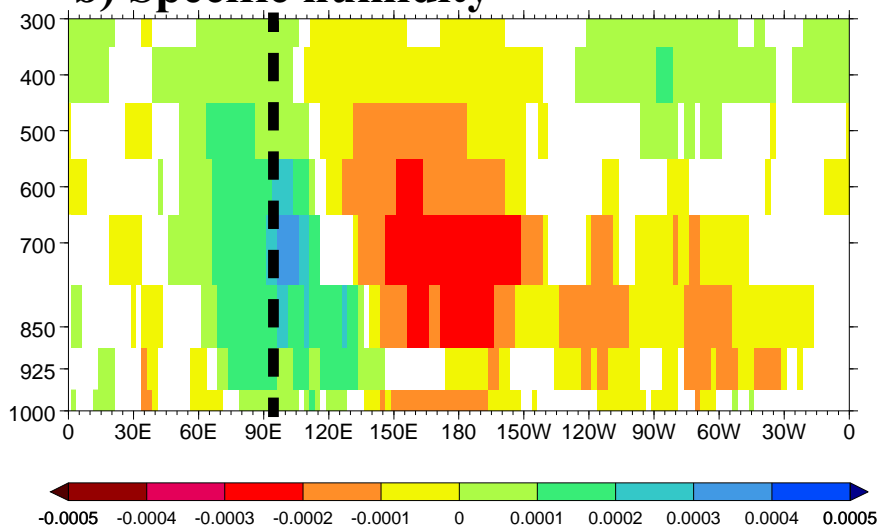

\section{c) u-wind}

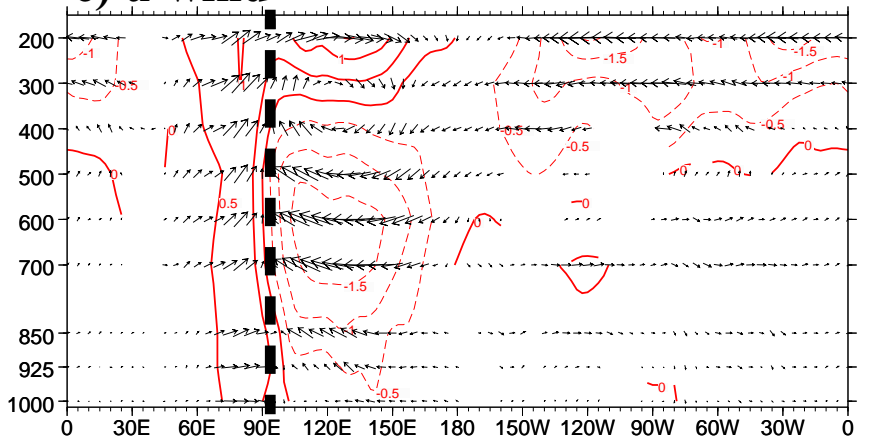

\section{d) Divergence}
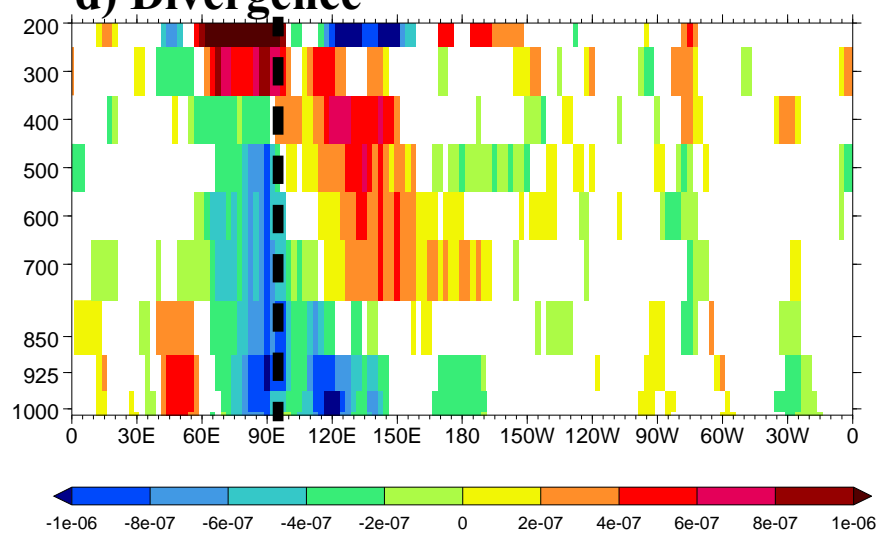

e) Specific humidity

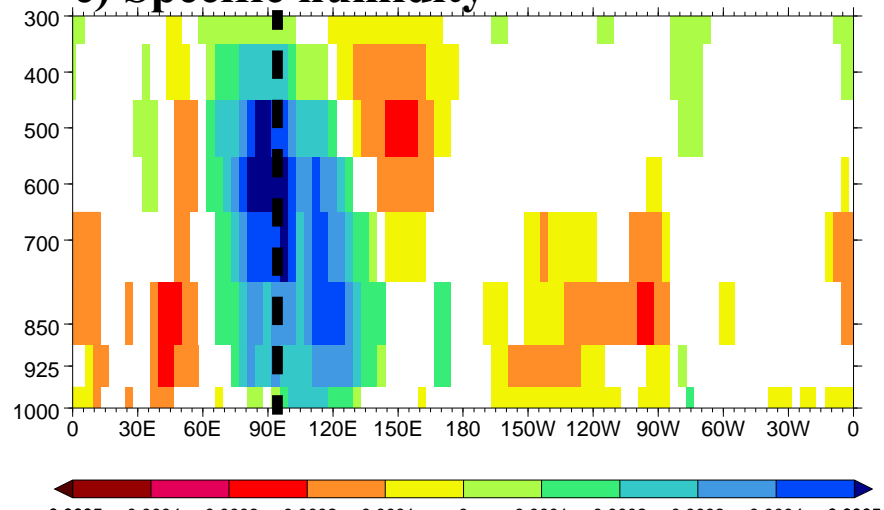

f) u-wind

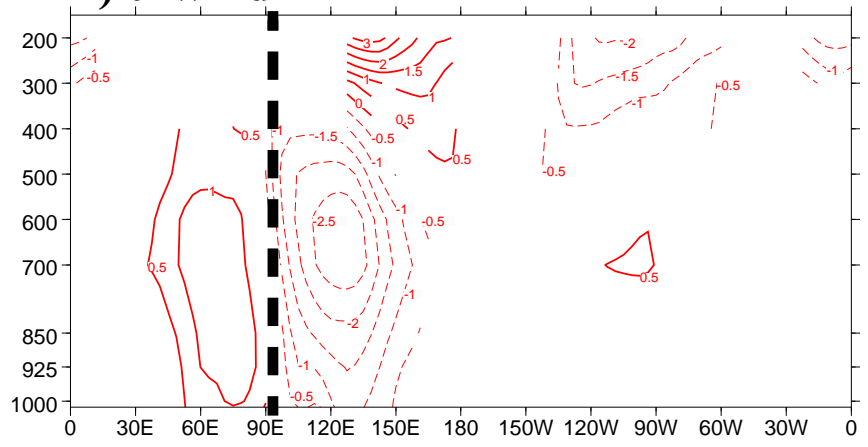


$5^{\circ} \mathrm{N}-5^{\circ} \mathrm{S}$ Lag-Pressure Level Regressions

\section{Observations}

a) Divergence

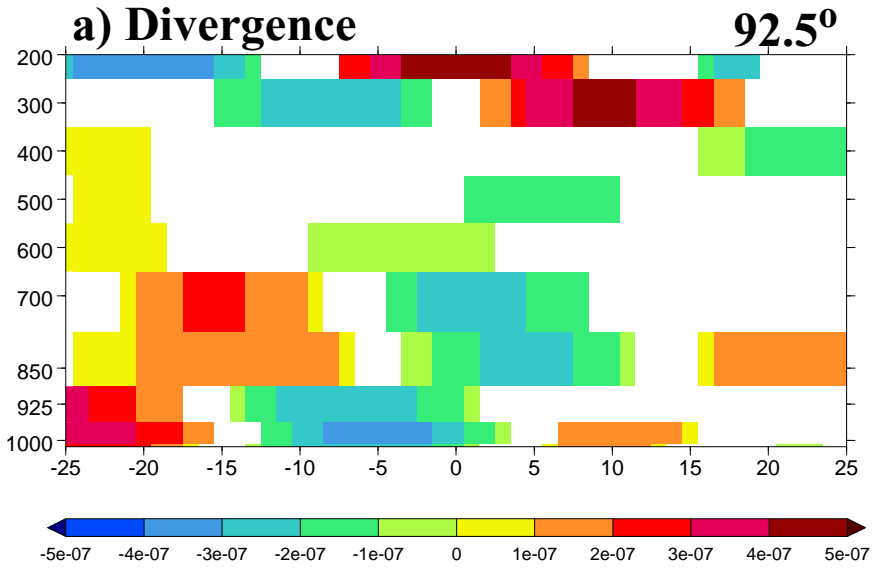

b) Specific humidity

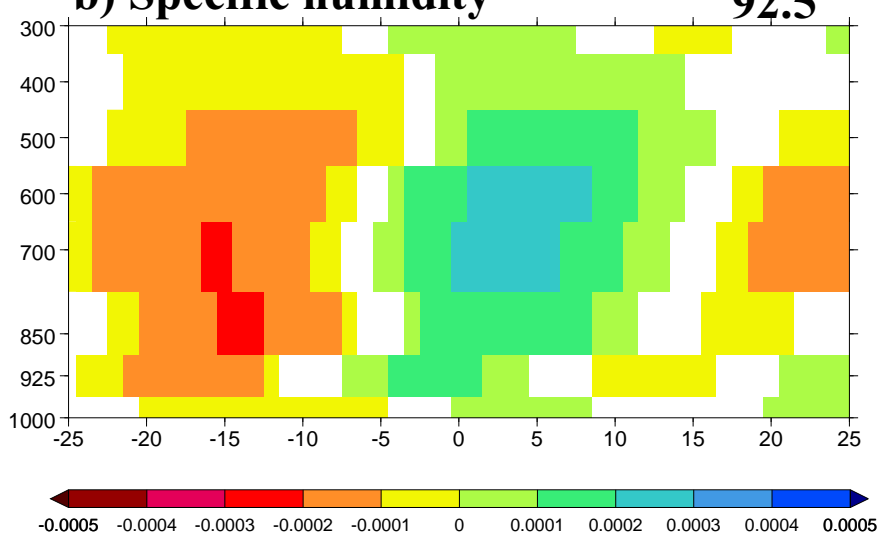

ECHO-G

c) Divergence

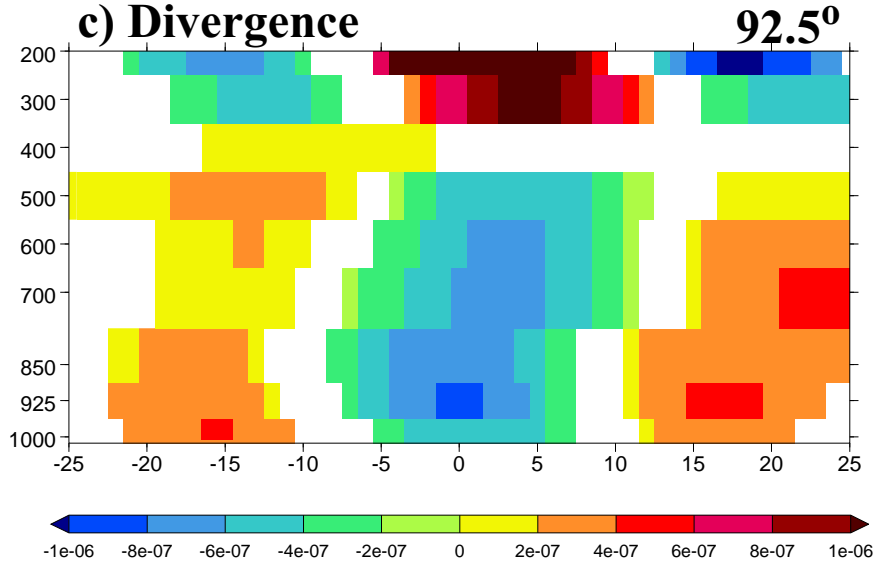

d) Specific humidity

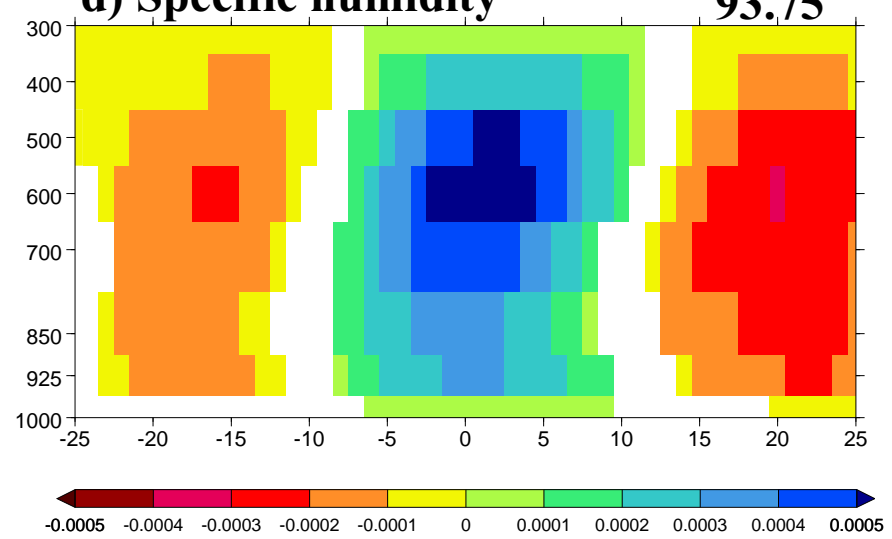


West Pacific Convection and Monsoon Break over India (Day 20)

Observations

a) CMAP Rainfall and $850 \mathrm{hPa}$ wind

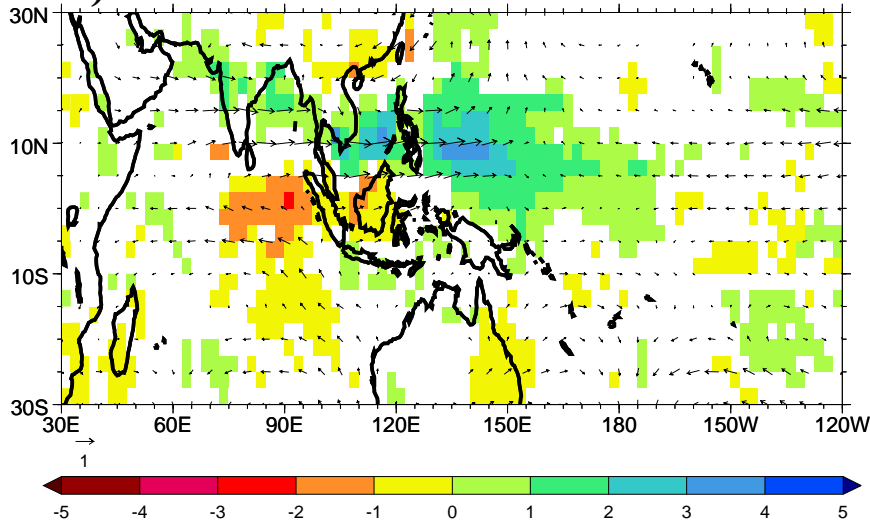

b) Surface Temperature and wind

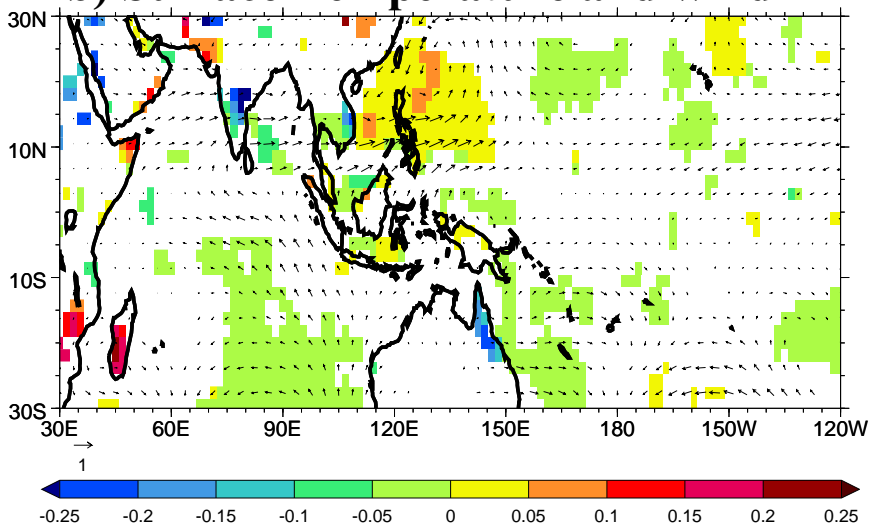

c) $1000 \mathrm{hPa}$ Divergence
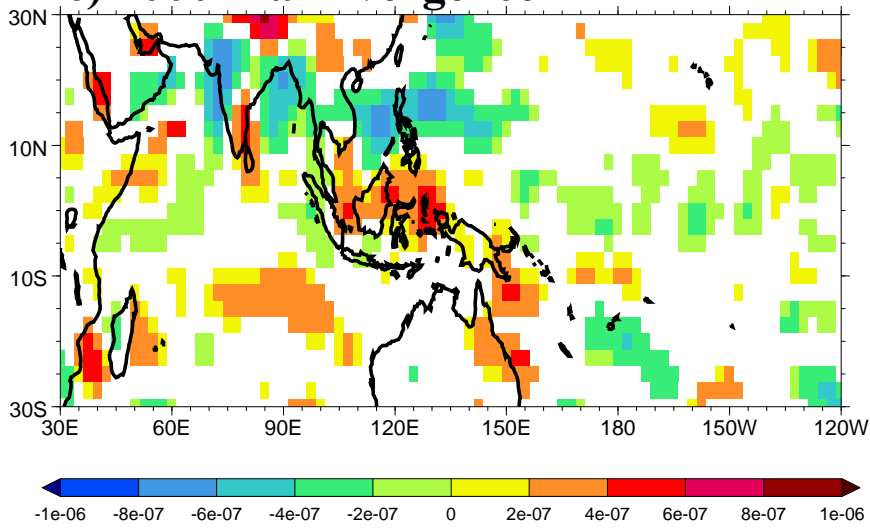

d) 850hPa Specific Humidity

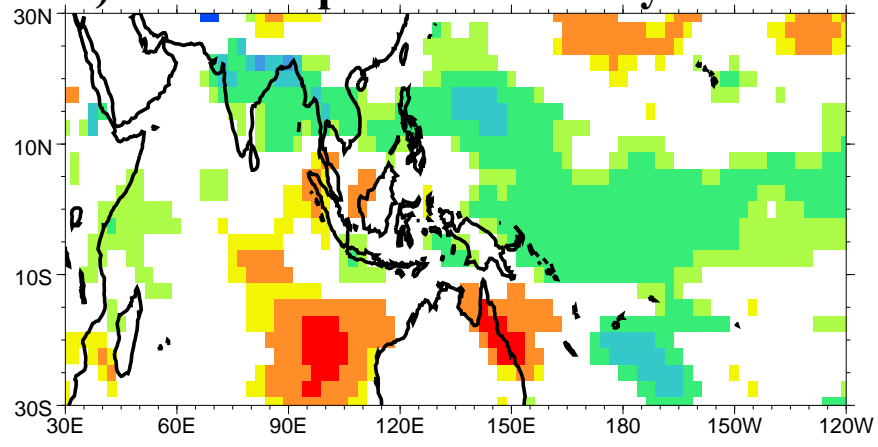

\begin{tabular}{|cccccc|c|cc|c|c|}
\hline & & & & & & & & & & \\
-0.0005 & -0.0004 & -0.0003 & -0.0002 & -0.0001 & 0 & 0.0001 & 0.0002 & 0.0003 & 0.0004 & 0.0005
\end{tabular}
ECHO-G

e) Rainfall and $850 \mathrm{hPa}$ wind

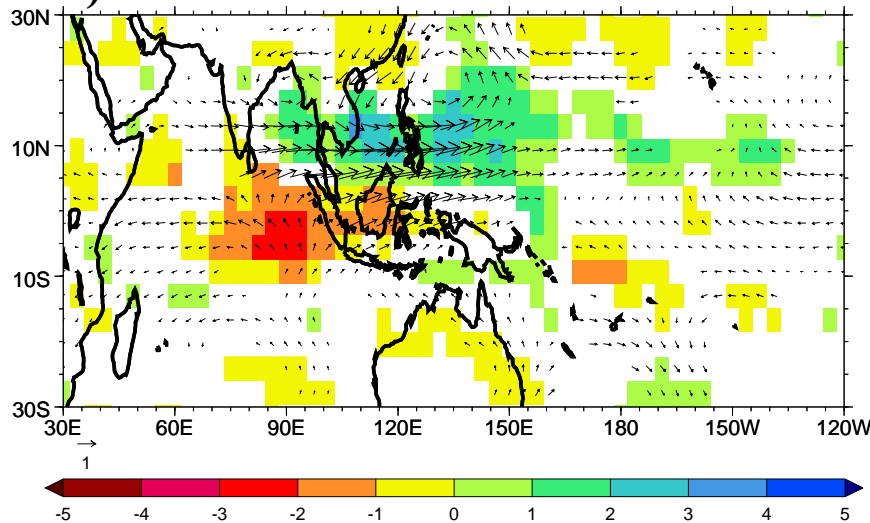

f) Surface Temperature and wind

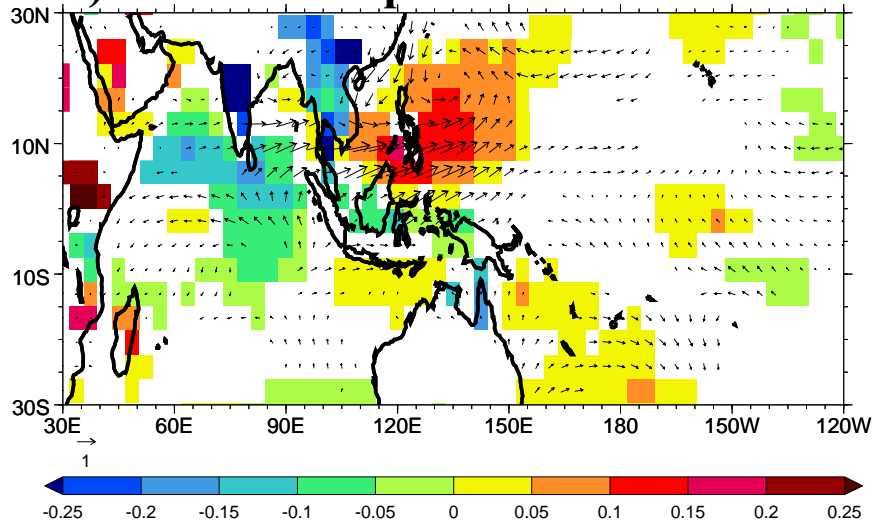

g) $1000 \mathrm{hPa}$ Divergence

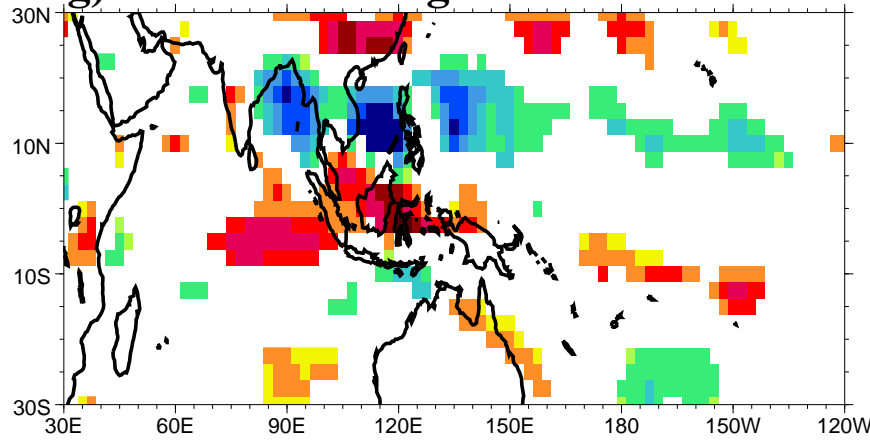

h) 850hPa Specific Humidity
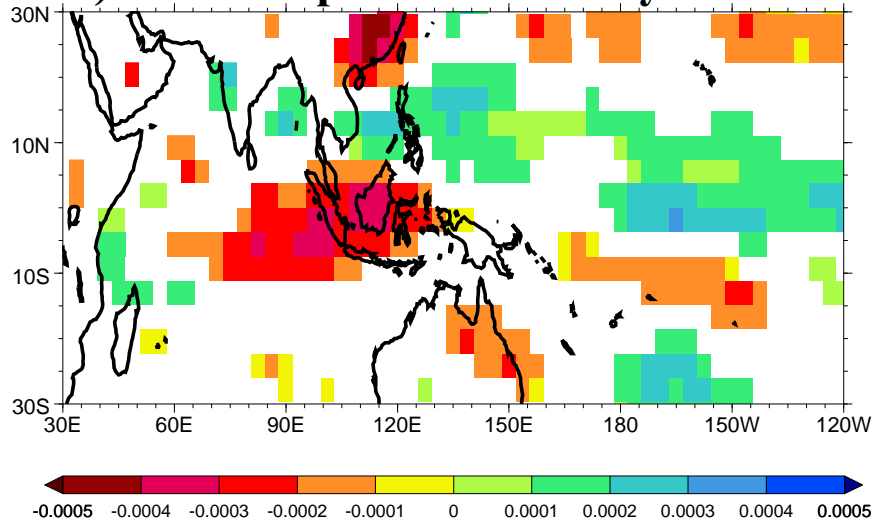
a) Positive heating over the tropical west Pacific

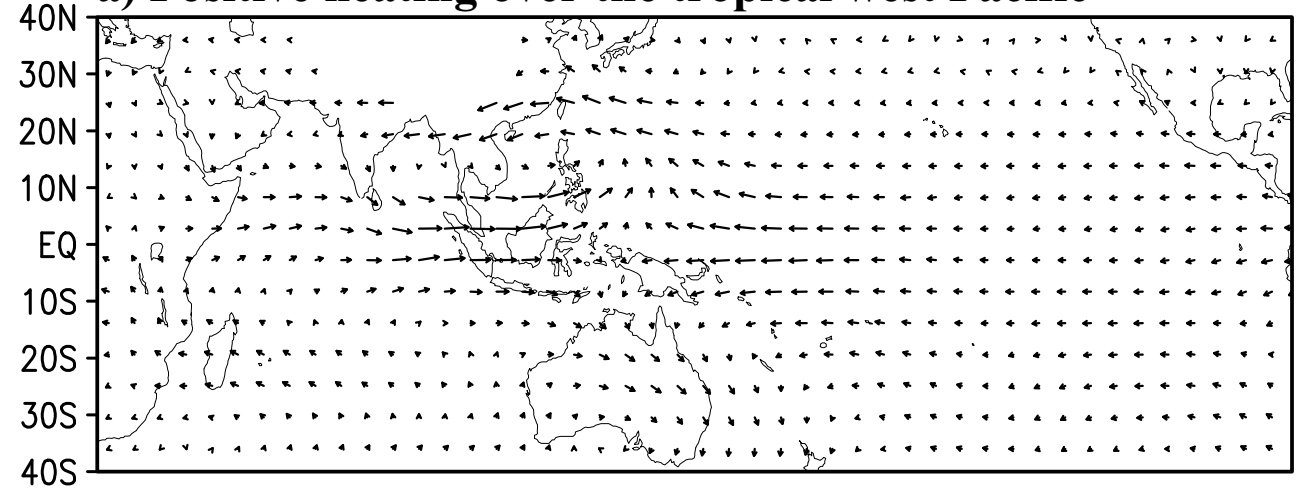

b) All heatings

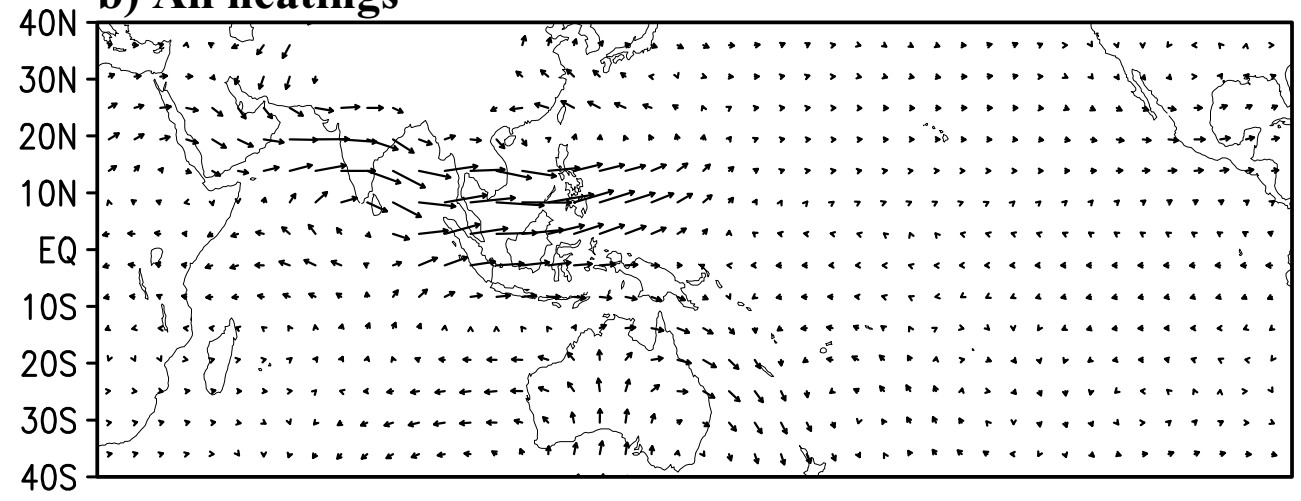

$\longrightarrow$

c) $\omega$ anomalies over India

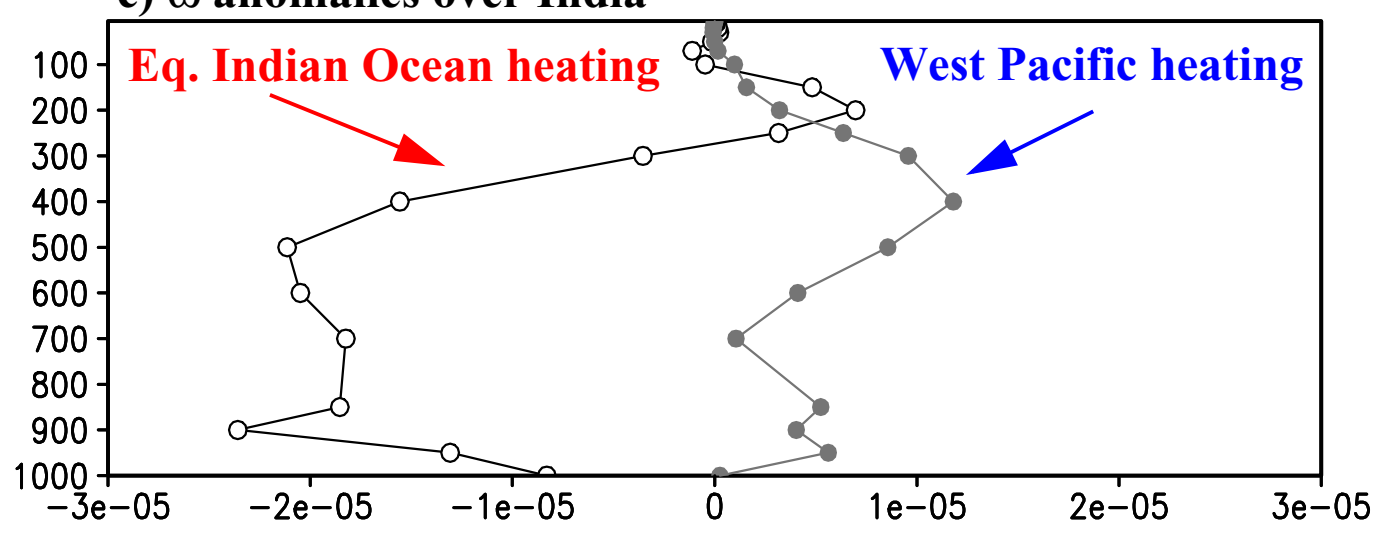




\section{Preliminary Findings}

1) The ECHO-G model captures the near-equatorial eastward intraseasonal propagation of convection, and its' poleward bifurcation over the eastern Indian Ocean

-the vertical structure and the low-level moisture convergence is consistent with the boreal winter MJO

2) In both model and observations above normal SST (and land surface temperature) lead the eastward and northward propagation of convection

3) For northward propagation, low-level moisture convergence leads the convection over the Indian longitudes, but not over the Bay of Bengal

4) However, the simulated northward propagation of convection over India is weaker than observed

5) The model represents the Annamalai and Sperber (2004) mechanism in which enhanced west Pacific convection helps trigger the monsoon break over India 